NASA Technical Memorandum 100850

AIAA-88-3016

\title{
Effect of Spatial Inlet Temperature and Pressure Distortion on Turbofan Engine Stability
}

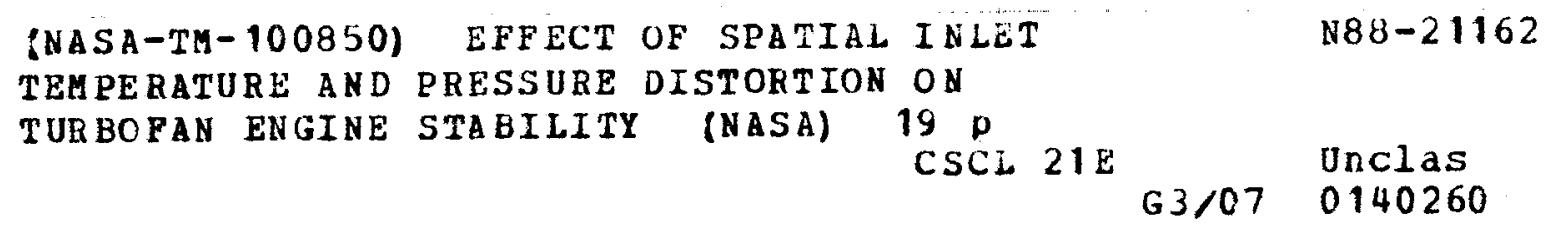

Charles M. Mehalic

Lewis Research Center

Cleveland, Ohio

Prepared for the

24th Joint Propulsion Conference

cosponsored by the AIAA, ASEE, ASME, and SAE

Boston, Massachusetts, July 11-13, 1988 


\author{
Charles M. Mehalic* \\ National Aeronautics and Space Administration \\ Lewis Research Center \\ Cleveland, Ohio 44135
}

\section{Abstract}

An experimental investigation was conducted in an altitude facility to determine the effects of steady-state inlet temperature distortion, pressure distortion, and combined temperature and pressure distortion on the stability of a PW1128 turbofan engine. The steady-state temperature

F distortion was generated by a gaseous-fueled

O hydrogen burner. Pressure distortion was pro-

if duced by a screen installed in the inlet ducting between the burner and the engine inlet. With the exceptions of inlet pressure distortion, a tipradial inlet temperature distortion at the highest corrected fan speed tested, and combined distortion with the low-pressure and high-temperature regions together, the fan generated a flow instability when operating near its steady-state stall line. In some instances the fan was not the first component to surge, however, because the instability disrupted the flow to the high-pressure compressor causing it to surge at, or near, the same time as the fan. The effect of combined distortion was dependent on the relative locations of the high-temperature and low-pressure regions; high-pressure compressor stall occurred when the distorted regions were together, and fan stall occurred when the distorted regions were diametrically opposed.

\section{Introduction}

A continuing problem encountered in the design and development of advanced airbreathing propulsion systems for military aircraft is the detrimental effect of nonuniform inlet flow on compression system performance and on stability limits. Inlet temperature distortion, both spatial and/or time variant, alone or combined with inlet pressure distortion, degrades engine performance and can result in total power loss by causing compression system components (fan or compressor) to stall. Inlet temperature distortion is of particular concern in applications relating to ingestion of hot gases from armament firing or catapult launch systems, from recirculation of erigine exhaust gases from thrust vectoring/ reversing systems, or from operation of helicopters and V/STOL aircraft. In the past, system operability problems caused by inlet temperature distortion have been solved by avoiding or minimizing the effect of the distortion through system configuration and/or operating procedure changes. This approach may not be adequate for propulsion systems of the future, and a better understanding of turbine engine response to inlet temperature distortion will be required.

An extensive experimental effort has been carried out at the Lewis Research Center to establish a data base for evaluating the effects of inlet flow distortion on the performance of turbine engine compression systems. This work

\footnotetext{
* Member AIAA.
}

includes investigations using turbojet ${ }^{-4}$, turbofan5-16, and turboshaft 17 engines subjected to spatial (steady-state) and time-variant inlet pressure distortion, inlet temperature distortion, and combinations of pressure and temperature distortion. As a result of these investigations, devices to generate the spatial and time-variant inlet temperature and pressure distortions were developed $18-20$.

The investigation reported herein is a continuation of the effort to establish an inlet flow distortion data base and to develop a better understanding of the effects of distortion on turbine engine performance. This report is concerned with the effect of spatial inlet temperature distortion and combined inlet temperature and pressure distortion on the stabllity limits of a Pratt \& Whitney Aircraft PWI128 turbofan engine. A gaseous-fueled hydrogen burner located upstream of the engine inlet was used to generate the temperature distortions, and a screen was used to produce inlet pressure distortion.

This investigation was conducted with circumferential temperature distortions of $90^{\circ}$ - and $180^{\circ}$-extent. Hub-radial and tip-radial temperature distortion patterns were also investigated. A $180^{\circ}$-extent total-pressure distortion, alone and in combination with a $180^{\circ}$-extent temperature distortion, was also tested. All tests were conducted in an altitude facility at an engine inlet Reynolds number index of 0.52 .

\section{Nomenclature}

A area, $\mathrm{ft}^{2}$

MPR multiple-per-revolution factor of circumferential temperature distortion

$\mathrm{N}_{1} \quad$ fan rotational speed, rpm

$\mathrm{N}_{2}$ high-pressure compressor rotational speed, rpm

P total pressure, psia

$T$ total temperature, ${ }^{\circ} \mathrm{R}$

W gas flow rate, $1 \mathrm{~b} / \mathrm{sec}$

$\Delta P / P$ intensity of circumferential totalpressure distortion

$\triangle P R S$ loss of stall pressure ratio

$\triangle T C / T$ intensity of circumferential temperature distortion

$\Delta T R / T$ intensity of radial temperature distortion

$\delta$ ratio of total pressure to absolute pressure of standard sea level conditions 
ratio of total temperature to absolute temperature of standard sea level conditions

\section{Subscrifts:}

\begin{tabular}{|c|c|}
\hline a & air \\
\hline avg & average \\
\hline cir & $\begin{array}{l}\text { circumferential average of all probes at } \\
\text { the same immersion depth }\end{array}$ \\
\hline j & exhaust nozzle throat \\
\hline rad & $\begin{array}{l}\text { radial average of all probes at the same } \\
\text { circumferential location }\end{array}$ \\
\hline t & total conditions \\
\hline 1 & airflow measuring station \\
\hline 2 & fan inlet \\
\hline $25 H$ & high-pressure compressor inlet \\
\hline $25 M$ & fan discharge, mixed \\
\hline 3 & high-pressure compressor exit \\
\hline
\end{tabular}

Apparatus and Instrumentation

Facility

The test program was conducted in one of the two altitude chambers of the Propulsion Systems Laboratory at the Lewis Research Center. These test cells are $24 \mathrm{ft}$ in diameter, $39 \mathrm{ft}$ long, and have the capability of simulating altitudes from near sea level to $80000 \mathrm{ft}$, with maximum airflow rates of 480 and $50 \mathrm{lb} / \mathrm{sec}$, respectively. Conditioning equipment is available to supply air temperatures ranging from -50 to $600^{\circ} \mathrm{F}$.

A photograph of the engine installed in the test cell is shown in Fig. 1. A direct-connect installation was used, with an inlet air bellmouth mounted in the plenum upstream of the test cell forward bulkhead. The engine was mounted on a two-dimensional (axial and lateral) thrust stand; conditioned air, at the desired pressure and temperature, was supplied through the inlet air bellmouth and ducting to the engine face. Test cell cooling air was supplied through a cooling air torus at the forward end of the test cell, and e hausters were available to maintain the desired altitude pressure in the test cell during testing.

\section{Engine}

An F100 EMDP (Engine Model Derivative Program; Pratt \& Whitney Aircraft des ignation PW1128) engine, serial number XO11, build 12 was used for this investigation. This engine is a low-bypassratio, high-compression-ratio, twin-spool turbofan consisting of the following parts: a three-stage fan driven by a two-stage, low-pressure turbine, a ten-stage compressor driven by a two-stage, aircooled high-pressure turbine, an annular combustor, a mixed-flow augmentor, and a variable area convergent-divergent exhaust nozzle. The augmentor was not used during the temperature distortion testing, but an exhaust nozzle plug was included as part of the installation to provide exhaust nozzle throat areas smaller than those obtainable with the standard nozzle. The plug was 14 in. in diameter and extended upstream of the exhaust nozzle primary throat.

The PWI128 engine is similar to the oroduction F100(3) engine but has a new, advanced fan design, an improved, high-pressure compressor, a recontoured combustor, higher temperature capability, high-and low-pressure turbines, and a digital electronic engine control (DEEC). Compared with the F100(3) fan, the PWI128 fan is designed for increased airflow, pressure ratio, and efficiency. The blade aspect ratio and number of blades were reduced; and a shroudless third-stage rotor blade, designed for increased core supercharging, was used. A one-piece fan case with removable tip shrouds was incorporated, and the intermediate case aft of the fan module included an integra? proximate splitter. The fan also has variable inlet guide vanes that are scheduled as a function of corrected fan speed.

A breadboard version of the DEEC was used during the temperature distortion tests. The breadboard unit enabled the on-line modification of schedules, logic, and control loops. The primary uses of the DEEC during the tests were maintaining constant corrected fan speed and providing manual control of the exhaust nozzle throat area. A further description of the DEEC is contained in Ref. 21.

\section{Temperature Distortion Generator}

A gaseous-fueled hydrogen burner was used to produce the steady-state temperature distortion patterns at the engine inlet. Hydrogen was used because it has both good ignition characteristics and rapid flame propagation speed, requires a low fuel-to-air ratio for a given temperature rise, and is clean burning (generating water vapor rather than pollutants). The burner was installed in the plenum upstream of the inlet duct bellmouth (Fig. 2(a)). The burner, which was divided into four individually controlled quadrants, had the capability of being rotated $30^{\circ}$ in either direction from top dead center. Quadrants were identified as 1 through 4 starting with the upper right and numbering in a clockwise direction looking upstream. Engine inlet airflow was heated in selected quadrants as it passed through the burner.

Each quadrant contained six annular gutters supported by one radial gutter and six circulartube manifolds (one in each annular gutter) with small holes for hydrogen injection ( $\mathrm{Fig} .2(\mathrm{~b})$ ). The six swirl-can pilot burners in each quadrant ignited the hydrogen flow to each gutter. A hydrogen manifold located outside the burner was connected by tubing and remotely operated flow control valves to the six circular-tube manifolds in each quadrant. The hydrogen manifolds were connected to the hydrogen supply by additional lengths of tubing and a remotely operated main flow control valve. With control of hydrogen flow to each individual quadrant, circumferential distortion with extents of $90^{\circ}, 180^{\circ}, 270^{\circ}$, and $360^{\circ}$ could be generated. Also, by shutting off hydrogen flow to selected gutters, hub- and tip-radial distortion patterns could be generated. 
Instrumentation

The instrumentation used for this test program is shown in Fig. 3. A schematic of the engine and installation ( $\mathrm{Fig} .3(\mathrm{a})$ ) shows the location of the measuring stations relative to the iniet duct and engine. Total pressure, static pressure, and total temperature were measured at each station. The type and number of instrumentation probes at each measuring station are presented in Fig. 3(b). Close-coupled (limited response) pressure transducers were installed at the fan inlet, fan duct, high-pressure compressor inlet, and high-pressure compressor exit. A limited number of high-response pressure measurements were available. These measurements were made by one Kulite transducer at the high-pressure compressor inlet and one Kulite transducer at the high-pressure compressor exit.

\section{Procedure}

The engine was run initially to establish baseline data for the fan with no inlet distortion. For these tests, conditioned air was supplied to the engine inlet at a total pressure of $6.65 \mathrm{psia}$ and a total temperature of $464^{\circ} \mathrm{R}$. Test cell altitude pressure was maintained at $4.36 \mathrm{psia}$. These conditions correspond to a flight condition of $30000 \mathrm{ft}$ with a Mach number of 0.8 (engine inlet Reynolds number index of $0.52)$. These same conditions were used for the iniet distortion tests with the exception of the 100 percent corrected fan speed data with temperature distortion, where an inlet temperature of $440^{\circ} R$ (engine inlet Reynolds number index of 0.56) was maintained to avoid engine overtemperature. Stall data were obtained by reducing exhaust nozzle throat area while maintaining constant corrected fan speed.

To obtain fan maps and stall data with steady-state inlet temperature distortion, the magnitude and extent of the distortion pattern was established by regulating hydrogen flow to the burner. For all temperature distortion patterns investigated, the temperature in the distorted region was nominally $50^{\circ} \mathrm{R}$ above the undistorted region $\left(\Delta T=50^{\circ} R\right)$. The corrected fan speed was set and held constant by the DEEC while the fan was forced to operate at increasingly higher pressure ratios by manually reducing the exhaust nozzle area incrementally until engine stall occurred. Following each incremental area reduction, the engine was allowed to stabilize and steady-state data were recorded. After engine stall occurred, engine operation was reestablished near stall, with the same distortion pattern and corrected fan speed; and the temperature distortion pattern was defined by recording data at several burner rotation settings, in effect moving the distortion pattern across the available instrumentation.

Stall data were obtained for $90^{\circ}$ - and $180^{\circ}$ extent circumferential temperature distortion patterns, $360^{\circ}$-extent hub-radial and tip-radial patterns, a $180^{\circ}$-extent circumferential pressure distortion pattern, and a $180^{\circ}$-extent circumferential temperature distortion combined with a $180^{\circ}$ extent circumferential total-pressure distortion produced by a screen upstream of the engine inlet.
These investigations were carried out over a range of corrected fan speeds from 80 to 100 percent of rated.

\section{Results and Discussion}

This test program was designed to determine fan sensitivity to steady-state inlet temperature distortion, inlet pressure distortion, and combined inlet temperature and pressure distortion. The engine manufacturer's examination of analog data recorded for each stall point revealed many instances in which the fan, as it approached the steady-state stall line, generated a flow instability that entered the high-pressure compressor and caused it to surge just before, or at the same time as, the fan. This flow instability was observed on the high-response pressure measurement (Kulite transducer) at the high-pressure compressor inlet when operating with an inlet temperature distortion pattern that influenced this highresponse measurement. Since flow instabilities have not been observed in other tests with similar temperature distortion generators, it appears that near-stall operation of the $f a n$ is the cause of the flow instability.

Typical distortion patterns that existed at near-stall conditions are presented for each distortion pattern tested. Fan maps showing the effect of inlet distortion on the stall line are included for the various distortion patterns.

\section{Component Maps Wi th Uniform Inlet Flow}

The fan and high-pressure compressor maps without inlet flow distortion are shown in Figs. 4 and 5 , respectively. Fan stalis were obtained at $80.0,90.1$, and 100.2 percent of rated corrected fan speed by manually reducing exhaust nozzle throat area while the DEEC maintained constant corrected speed. The stall points were extrapolated from data plots of pressure ratio and corrected airflow as a function of exhaust nozzle throat area. The high-pressure compressor map (Fig. 5) was generated from data obtained in another test program with the same engine where an inflow bleed system was used to backpressure the compressor at constant corrected speed. The program in which the high-pressure compressor map was generated was interested primarily in subidle speed operation, so the speed ranges of the two maps do not coincide: the highest corrected highpressure compressor speed matches approximately with the lowest corrected fan speed tested.

\section{Inlet Temperature Profiles}

Examples of typical fan and high-pressure compressor inlet temperature distortion profiles are shown in Figs. 6 to 9 . Tables 1 and 2 contain a complete description of all the temperature distortion patterns tested. The circumferential oneper-revolution and hub-radial patterns (Figs. 6 to 8) were recorded at 80 percent corrected fan speed with the exhaust nozzle throat area approximately $0.1 \mathrm{ft}^{2}$ larger than was required to initiate stall. The tip-radial pattern (Fig. 9) was recorded at 90 percent corrected fan speed with the exhaust nozzle $0.16 \mathrm{ft}^{2}$ larger than required for stall. 
The steady-state spatial temperature distortion patterns are described in terms of circumferential extent, circumferential intensity, and radial intensity. These descriptors, similar to those defined for inlet pressure distortion in Refs. 22 and 23 , are obtained by substituting high temperature for low pressure as the destabilizing factor. The extent descriptor is an indication of the circumferential size of the high-temperature region, and the intensity descriptors are indications of the magnitude of the temperature distortion. The distortion pattern extent is defined as the circumferential extent of the high-temperature region obtained from a linear interpolation of the circumferential profile and its intersection with the average temperature of the profile. The circumferential intensity, $(\Delta T C / T)$, is defined as the difference between the high-temperature region average temperature and the profile average temper ature ratioed to the profile average temperature. The radial temperature distortion intensity, $(\Delta T R / T)$, is defined as the difference between the maximum high temperature in the radial profile and the profile average temperature ratioed to the profile average temperature.

The spatial temperature distortion produced by burning in one quadrant of the hydrogen burner is shown in Fig. 6. Based on the above definitions, the distortion at the fan inlet has an extent of $132^{\circ}$ with a circumferential intensity of 0.045 and a radial intensity of 0.006 . The circumferential intensity does not reflect the true value, which may be slightly higher, because the instrumentation was located such that even with burner rotation peak temperatures were not measured. The shape of the actual pattern at the fan inlet is more like that shown for the high-pressure compressor inlet (Fjg. $6(\mathrm{~b})$ ). The temperature distortion pattern, which follows a particle path through the fan, is rotated approximately $70^{\circ}$ in the direction of rotor rotation as it passes through the fan. At the high-pressure compressor inlet, the distortion has a circumferential extent of $118^{\circ}$ with circumferential and radial intensities of 0.038 and 0.011 , respectively.

Figure 7 shows the temperature distortion profiles produced by burning in two adjacent quadrants of the hydrogen burner in an attempt to create a $180^{\circ}$-extent circumferential pattern. The profile at the fan inlet has an extent of $180^{\circ}$ with a circumferential intensity of 0.047 and a radial intensity of 0.009 . Here again, the temperature distortion pattern rotates approximately $70^{\circ}$ while passing through the fan. At the highpressure compressor inlet the profile has an extent of $192^{\circ}$. The actual extent, however, is probably closer to $180^{\circ}$, but sufficient instrumentation was not available to completely define the profile at this station. The circumferential and radial intensities at the high-pressure compressor inlet are 0.043 and 0.010 , respectively. Based on the circumferential intensities in Table 1, the distortion amplitude at the fan inlet is attenuated by an average of approximately 15 percent before it reaches the high-pressure compressor inlet.

The circumferential and radial temperature profiles at the fan and high-pressure compressor inlets for a hub-radial distortion are presented in Fig. 8. The circumferential profiles exhibit multiple low intensity (less than l percent) hightemperature regions. The distortion descriptors for this type of multiple-per-revolution (MPR) distortion pattern are also similar to those defined in Refs. 22 and 23 . The extent and intensity of the circumferential distortion correspond to the region that has the highest product of extent and intensity. Also included in the pattern description is an MPR factor which is defined as the number of equivalent high-temperature regions based on the ratio of the sum of the products of the extents and intensities for each high-temperature region, to the region with the largest product of extent and intensity. Based on these descriptors and those defined previously, the circumferential distortion at the fan inlet has an extent of $100^{\circ}$ degrees, a circumferential intensity of 0.008 , and an MPR factor of 1.563 . The radial temperature distortion intensity is 0.072. At the high-pressure compressor inlet (Fig. 8(b)), the radial intensity is 0.069 and the circumferential extent is $108^{\circ}$ with an intensity of 0.007 and an MPR of 1.085 . Although this is an attenuation of approximately 4 percent between the fan inlet and the high-pressure compressor inlet. the attenuation of radial temperature distortion for all the hub-radial patterns listed in Table 1 ranges from 4 to 17 percent.

The tip-radial temperature distortion pattern (Fig. 9) exhibits the same circumferential characteristics as the hub-radial pattern in that a lowintensity MPR distortion exists at the fan and high-pressure compressor inlets. The radial distortion at the fan inlet is confined to the bladetip region and, as expected, is not present at the high-pressure compressor inlet. At the fan inlet, the distortion has an extent of $139^{\circ}$, a circumferential intensity of 0.009 , and an MPR of 1.353 . The radial intensity is 0.034 . The distortion transferred through the fan to the high-pressure compressor inlet has an extent of $107^{\circ}$, an MPR of 1.844, and circumferential and radial intensities of 0.010 and 0.013 , respectively.

In general, temperature distortion patterns produced by the hydrogen burner were of the type desired. The circumferential patterns exhibited very small radial components and, likewise, the radial temperature distortion patterns contained very little circumferential distortion.

\section{Circumferential Inlet Temperature Distortion}

Circumferential one-per-revolution inlet temperature distortion patterns of two extents were generated by heating the inlet ajrflow with either one burner quadrant or two adjacent burner quadrants. The tests were conducted for both extents with the distortion in the top and bottom regions of the fan inlet in an attempt to determine the effect on fan stability of the location of fan inlet temperature sensors used for scheduling variable geometry. In all cases the heated regions were approximately $50^{\circ} R$ hotter than unheated regions, which resulted in distortion intensities that were nearly constant throughout the test program. Descriptors of all the circumferential temperature distortion patterns tested are shown in Table 1. The entries missing from Table 1 were not available because profile information (based on burner rotation data) was not 
recorded. In the case where high-pressure compressor inlet conditions are missing (quadrant 2), the instrumentation at that station was insufficient to detect the distortion pattern. With the small variations in extent and intensity among the patterns, data correlations could be made by assuming a missing entry could be replaced by the value above it.

The results of operation with fan inlet circumferential temperature distortion indicated that as the fan approached its steady-state stall line a flow instability was generated. The flow instability generated by the fan caused the highpressure compressor to surge just before, or nearly at the same time as, the fan. Table 1 lists the high-pressure compressor corrected speeds of the last steady-state data point recorded before stall, whereas the fan speeds are the constant values maintained during the exhaust nozzle area reduction. It should be noted that, although corrected fan speed was held constant during the nozzle area reduction, the rematch of the fan and compressor resulted in an increase of corrected high-pressure compressor speed.

The fact that the fan was operating near stall prior to engine surge can be illustrated by using simple parallel compressor theory. This theory assumes that a compressor can be separated into a discrete number of parallel flow paths operating at the same mechanical speed and exit static pressure, but with different inlet total pressures and temperatures. The performance of each segment is assumed to be the same as that obtained with uniform flow conditions at the segment inlet. Each segment may operate with a different corrected speed, operating point, and stall margin. Stall initiates when any of the segments is forced to operate above the stall line defined with uniform inlet flow.

The excursion of the fan operating point during the exhaust nozzle area reduction, with a $180^{\circ}$-extent circumferential distortion, is shown in Fig. 10. The distortion pattern descriptors are given in Table 1 as pattern number 7 . Fan speed was held constant at 91.3 percent corrected as shown by the average operating points of Fig. 10. During this exhaust nozzle area reduction, the corrected speed of the high-pressure compressor increased from 94.8 to 96.0 percent, while the average high-pressure compressor operating point moved along its operating line. The fan operating points are plotted on the component map obtained with uniform iniet flow. Splitting the fan into two segments using parallel compressor theory resulted in the hot-side and cold-side corrected fan speed lines shown in Fig. 10. The hot and cold sides operate at the same pressure ratio as the average points, but with different inlet temperatures and, therefore, different corrected speeds. This forces the segment with the high inlet temperature to approach the steady-state stall line as the exhaust nozzle area is reduced. For the average steady-state stall point (flagged symbol in Fig. 10), the heated portion of the fan is operating above the steady-state stall line with uniform inlet flow.

Fan maps showing the effect of single quadrant burner heating on fan performance are presented in Figs. 11 and 12 . The results shown in
Fig. 11 occured with the temperature distortion in quadrant 4 at the fan inlet (unheated inlet temperature sensors) whereas Fig. 12 presents results with heating in quadrant 2 (heated inlet temperature sensors). In both figures, it is evident that the inlet temperature distortion causes a loss in fan stall pressure ratio (measured at constant corrected airflow) at all speeds. In Fig. 11 the loss in fan stall pressure ratio at $78.9,88.9$, and 99.0 percent corrected speed is $8.1,6.6$, and 6.4 percent respectively, for a circumferential inlet temperature distortion with an extent of $133^{\circ}$ and a magnitude of 4.5 percent (patterns 1,2, and 3 of Table 1). From Fig. 12, the loss of fan stall pressure ratio at 82.7 and 92.9 percent corrected speed is 9.4 and 9.3 percent respectively, for patterns 4 and 5 of Table 1.

Similarly, Figs. 13 and 14 present the effect on fan performance of operating with heating in two adjacent quadrants of the burner. When the inlet temperature sensors are unheated (Fig. 13), the inlet distortion (patterns 9 to 11 of Table i) causes fan stall pressure ratio losses of $13.2,9.5$, and 6.3 percent at $78.0,88.0$, and 97.7 percent corrected speed respectively. With the inlet temperature sensors heated by the inlet temperature distortion ( $\mathrm{Fig} .14$ ), the resulting loss in fan stall pressure ratio is $10.6,8.7$, and 6.6 percent at $81.1,91.3$, and 102.0 percent corrected speed respectively.

As mentioned earlier, one of the objectives of the test program was to determine the effect of fan inlet temperature sensor location on stability. When the sensors detect either the hot or cold part of the distorted flow, the control adjusts variable geometry accordingly; and changes the fan stall margin differently from when the sensors detect the average temperature. The PW1128 engine has inlet temperature sensors located in the bottom half of the fan inlet. Both single quadrant and adjacent quadrant heating was tested with the distortion in the top and bottom at the fan inlet. Comparison of $\mathrm{Fig} .13$ with Fig. 14 shows that, for a $180^{\circ}$-extent temperature distortion at the low corrected fan speeds $(78.0$ to 81.1 percent), a greater loss in stall pressure ratio occurs when the sensors are located outside the temperature distortion (unheated). Similar results have been reported. 4

\section{Radial Inlet Temperature Distortion}

The hub- and tip-radial iniet temperature distortion patterns that were tested with the PWl128 engine are described in Table 2. Both types of radial patterns exhibit low levels of MPR circumferential distortion similar to that shown in Figs. 8 and 9 . The tip-radial pattern is not transferred to the high-pressure compressor inlet, whereas the hub-radial distortion passes through the fan and appears at the high-pressure compressor inlet, attenuated from 4 percent at the low speed to 17 percent at the highest speed tested. Entries not appearing in Table 2 were omitted because pattern definition from burner rotations was not recorded, and the limited instrumentation at both fan and high-pressure compressor inlet stations was insufficient to accurately define the low-level MPR circumferential content. 
As was the case with circumferential temperature distortion, radial inlet temperature distortions resulted in a loss in fan stall pressure ratio. In some instances, a flow instability generated by the fan operating near stall (similar to that recorded with circumferential temperature distortion) was observed and caused the highpressure compressor to stall just before, or near the same time as, the fan. The high-pressure compressor speeds listed in Table 2 are those of the last steady-state data point recorded before stall.

The results with tip-radial temperature distortion are shown on the fan map of $\mathrm{Fig} .15$. Fan stalis occurred at constant corrected fan speeds of 80.8 and 91.2 percent. At 96.2 percent speed, a flow instability generated by the fan was not observed, but it appears that stall was initiated in the high-pressure compressor; therefore, a fan stall point is not included for the high corrected speed, although it is believed the fan was operating close to its steady-state limit. The highpressure compressor stall at the high speed may be due to the increased circumferential intensity of distortion pattern 3 at the high-pressure compressor inlet $(0.016$ compared to 0.010 or less for patterns 1 and 2 ), since the radial content at the high-pressure compressor inlet is about the same as pattern 2. For the fan, the tip-radial temperature distortion at 80.8 percent speed (pattern 1 , Table 2) resulted in a loss of stall pressure ratio ( $\triangle P R S$ ) of 10.6 percent, defined at constant corrected airflow as in Refs. 22 and 23 . At 91.2 percent corrected speed, pattern 2 of Table 2 caused a $\triangle P R S$ of 5.7 percent.

Results with $360^{\circ}$-extent hub-radial temperature distortion are shown in Fig. 16. At each speed, stall initiated in the fan with distortion patterns 4,5 , and 6 (Table 2). The hub-radial temperature distortion caused fan stall pressure ratio losses of 5.0 percent at 78.4 percent corrected speed, 6.1 percent at 88.3 percent corrected speed, and 5.3 percent at 98.4 percent corrected speed.

\section{Circumferential Inlet Total-Pressure Distortion}

The engine was tested with circumferential inlet total-pressure distortion at corrected fan speeds of 90.2 and 100.2 percent. The pressure distortion was produced by a $180^{\circ}$ sector of 5 1/2-mesh screen $(0.063-i n .-d i a m$ wire) installed in the bottom half of the inlet duct upstream of the fan inlet. The total-pressure profiles at the fan inlet for the last steady-state data points recorded prior to stall are shown in Fig. 17. Based on the methods of Refs. 22 and 23 for calculating pressure distortion descriptors. the patterns exhibit circumferential extents of $183^{\circ}$ at both speeds with circumferential intensities $(\Delta P / P$ ) of 0.042 at the low speed ( $F i g .17(a)$ ) and 0.072 at the high speed (Fig. 17(b)). For both speeds, no significant radial total-pressure distortion existed. The instrumentation at the high-pressure compressor inlet was not adequate to define the profile at that station nor to determine the pressure distortion transfer characteristics of the fan.

The effect of inlet total-pressure distortion on fan stability is shown superimposed on the uniform inlet flow fan map in Fig. 18. As was the case with inlet temperature distortion, the fan stall line with inlet pressure distortion was defined by reducing exhaust nozzle throat area while maintaining corrected fan speed constant. At 90.2 percent corrected fan speed, the totalpressure distortion (Fig. 17(a)) resulted in a 6.2 percent loss of stall pressure ratio (DPRS). The effect of the pressure distortion at

100.2 percent corrected speed was an 8.3 percent loss in stall pressure ratio.

\section{Combined Temperature and Pressure Distortion}

Two configurations of combined temperature and pressure distortion were tested. One was with diametrically opposed $180^{\circ}$-extent sectors (pressure distortion over the bottom half of the fan inlet), and the other had the $180^{\circ}$-extent sectors of temperature and pressure distortion together over the bottom half of the fan inlet. The instrumentation was adequate to define the pressure distortion profiles at each speed, but the burner was not rotated to define the temperature distortion profiles. It should be assumed that the temperature distortion patterns described in Table 1 (patterns 6 to 8 for the distortions together and patterns 9 to 11 for the distortions opposed) existed during these combined distortion tests, since hydrogen flow to the burner was adjusted to essentially the same values as those used to produce the patterns of Table 1.

The combined distortion had a very severe effect on high-pressure compressor stability when the distorted sectors were together. Results of attempts to map the fan with the distortions together are shown in Fig. 19. Analysis by the engine manufacturer of analog records of the stall points indicated that all stalls with the distorted sectors together initiated in the highpressure compressor; therefore fan stall points are not included on Fig. 19. Fan pumping capability does not appear to be affected by the combined distortion. (The speed line shape is similar to those produced with uniform inlet flow.) Attempts to map the fan at 91.5 percent speed were unsuccessful because the high-pressure compressor was operating very near its steady-state stall limit at all exhaust nozzle area settings. The steadystate point (Fig. 19, 91.5 percent speed) was recorded, and the high-pressure compressor stalled before any changes in operating point were attempted. other attempts were made to map this speed line. with the same result.

When the combined distortion was tested with the high-temperature and low-pressure regions diametrically opposed, stalls at all speeds initiated in the fan instead of the high-pressure compressor. This result, that opposed temperature and pressure distortions have less effect on the stability of a component than do distortions that are together has been documented in other test programs. 4,17 The results of the fan mapping with opposed temperature and pressure distortions are shown in Fig. 20. The loss in fan stall pressure ratio with this combined distortion pattern was 3.4 percent at 77.8 percent corrected fan speed. 8.6 percent at 87.8 percent corrected fan speed, and 8.4 percent at the highest corrected fan speed tested. The high-pressure compressor speeds corresponding to the fan stall points were 92.9 , 95.8 , and 98.8 percent. 
Summary of Results

A PWli28 turbofan engine was tested at altitude conditions with steady-state inlet temperature distortion, pressure distortion, and combined temperature and pressure distortion. A gaseousfueled hydrogen burner located upstream of the engine inlet was used to produce the circumferential and radial temperature distortion patterns. Inlet pressure distortion was created with a screen in the inlet ducting. Tests with combined temperature and pressure distortion included varying the relative positions of the high-temperature and low-pressure regions. The following results were obtained:

1. Temperature distortion patterns produced by the hydrogen burner consisted of the desired pattern: circumferential patterns had little radial content, and likewise, radial patterns had little circumferential content.

2. Circumferential temperature distortion rotated approximately $70^{\circ}$ in the direction of rotor rotation as it passed through the fan; and although it was attenuated about 15 percent, the distortion initiated a flow instability in the fan, as it operated near its steady-state stall limit, that caused the high-pressure compressor to stall just before, or near the same time as, the fan.

3. Hub-radial temperature distortion, which was attenuated from 4 to 17 percent in passing through the fan, initiated a flow instability in the fan with results similar to those observed with circumferential inlet temperature distortion.

4. Tip-radial temperature distortion resulted in fan stall at 80.8 and 91.2 percent corrected fan speed and caused stall pressure ratio losses of 10.6 and 5.7 percent, respectively. A tipradial temperature distortion at 96.2 percent corrected fan speed appeared to cause high-pressure compressor stall. The circumferential distortion content of the pattern at 96.2 percent speed may have been a contributing factor since the circumferential distortion intensity at the high-pressure compressor inlet was about double that observed at the lower speeds.

5. Circumferential inlet total-pressure distortion caused the fan to stall. An intensity of 4.2 percent caused a 6.2 percent loss in stall pressure ratio at 90.2 percent corrected fan speed, and an intensity of 7.2 percent resulted in an 8.3 percent stall pressure ratio loss at 100.2 percent corrected speed.

6. The ability of pressure and temperature distortion to cancel each other's effect on stability was demonstrated. Combined distortion with the high-temperature and low-pressure regions together caused stall to initiate in the highpressure compressor. When combined distortion with the high-temperature and low-pressure regions opposite each other was tested, the effect on high-pressure compressor stability was reduced to the point that stall initiated in the fan.

\section{REFERENCES}

1. Gabriel, D., Wallner, L., Lubick, R., and Vasu, G., "Some Effects of Inlet Pressure and Temperature Transients on Turbojet Engines," Aeronautical Engineering Review, vol. 16, No. 9, Sept. 1957, pp. 54-59, 68.

2. Wallner, L.E., Useller, J.W., and Saari, M.J., "A Study of Temperature Transients at the Inlet of a Turbojet Engine," NACA RM-E57C22, June $26,1957$.

3. Braithwaite, W.M., Graber, E.J. Jr., and Mehalic, C.M., "The Effect of Inlet Temperature and Pressure Distortion on Turbojet Performance," AIAA Paper 73-1316, Nov. 1973. (NASA TM $X-71431$ ).

4. Mehalic, C.M. and Lottig, R.A., "Steady-State Inlet Temperature Distortion Effects on the Stall Limits of a J85-GE-13 Turbojet Engine," NASA TM X-2990, 1974.

5. Wenzel, L.M., "Experimental Investigation of the Effects of Pulse Pressure Olstortions Imposed on the Inlet of a Turbofan Engine," NASA TM X-1928, 1969.

6. Rudey, R.A. and Antl, R.J., "The Effect of Inlet Temperature Distortion on the Performance of a Turbofan Engine Compressor System," AIAA Paper 70-625, June 1970. (NASA TM $X-53788$ )

7. McAulay, J.E., "Effect of Dynamic Variations in Engine Inlet Pressure on the Compressor System of a Twin-Spool Turbofan Engine," NASA TM X-2081, 1970.

8. Braithwaite, W.M., "Experimental Evaluation of a TF30-P-3 Turbofan Engine in an Altitude Facility: Effect of Steady-State Temperature Distortion," NASA TM X-2921, 1973.

9. deBogdan, C.E., Dicus, J.H., Evans, D.G., and Soeder, R.H., "Effect of a 180-degree Extent Inlet Pressure Distortion on the Internal Flow Conditions of a TF30-P-3 Engine," NASA TM X-3267, 1975 .

10. Abdelwahab. M., "Effects of Temperature Transients at Fan Inlet of a Turbofan Engine," NASA TP-1031, 1977.

11. Braithwaite, W.M. and Soeder, R.H., "Combined Pressure and Temperature Distortion Effects on Internal flow of a Turbofan Engine, "AIAA Paper 79-1309, June 1979. (NASA TM-79136).

12. Soeder, R.H. and Bobula, G.A., "Effect of Steady-State Pressure Distortion on Flow Characteristics Entering a Turbofan Engine," NASA TM-79134, 1979.

13. Soeder, R.H. and Bobula, G.A., "Effect of Steady-State Temperature Distortion and Combined Distortion on Inlet Flow to a Turbofan Engine," NASA TM-79237, 1979. 
14. Abdelwahab, M., "Effects of Fan Inlet Temperature Disturbances on the Stability of a Turbofan Engine," NASA TM-82699, 1981.

15. Soeder, R.H. and Mehalic, C.M., "Effect of Combined Pressure and Temperature Distortion Orientation on High-Bypass-Ratio Turbofan Engine Stability," NASA TM-83771, 1984.

16. Soeder, R.H., Mehalic, C.M., and Stancik, K., "Effect of Steady-State Temperature Distortion on Inlet Flow to a High-Bypass-Ratio Turbofan Engine," NASA TM-86896, 1985.

17. Biesiadny, T.J., Klann, G.A., and Little, J.K., "Response of a Small-Turboshaft-Engine Compression System to Inlet Temperature Distortion," NASA TM-83765, 1984.

18. Meyer, C.L., McAulay, J.E., and Biesiadny, T.J. "Technique for Inducing Controlled Steady-State and Dynamic Inlet Pressure Disturbances for Jet Engine Tests, "NASA TM $X-1946,1970$.
19. Baumbick, R.J., "Device for Producing Dynamic Distortion Patterns at Inlets of Air-Breathing Engines," NASA TM X-2026, 1970.

20. Klann, G.A., Barth, R.L., and Biesiadny, T.J., "Temperature Distortion Generator for Turboshaft Engine Testing," Advances in Aerospace Propulsion, SAE SP-594, SAE, Warrendale, PA, 1984, pp. 89-99. (NASA TM-83748).

21. Burcham, F.W. Jr., Meyers, L.P., and Zeller, J.R., "Flight Evaluation of Modifications to a Digital Electronic Engine Control system in an F15 Airplane," AIAA Paper 83-0537, Jan. 1983. (NASA TM-83088).

22. "Gas Turbine Engine Inlet Flow Distortion Guidelines," SAE ARP-1420, SAE, Mar. 1978.

23. "Inlet Total-Pressure-Distortion Considerations for Gas Turbine Engines, "SAE AIR-1419, SAE, May 1983.

TABLE I. - CIRCUMFERENTIAL INLET TEMPERATURE DISTORTION PATTERNS

\begin{tabular}{|c|c|c|c|c|c|c|c|c|c|}
\hline \multirow[t]{2}{*}{ Pattern } & \multirow[t]{2}{*}{$\begin{array}{l}\text { Heated } \\
\text { quadrants }\end{array}$} & \multirow{2}{*}{$\begin{array}{l}\text { Fan speed. } \\
\text { percent } \\
\text { corrected }\end{array}$} & \multicolumn{3}{|c|}{ Fan inlet conditions } & \multirow{2}{*}{$\begin{array}{l}\text { High-pressure } \\
\text { compressor } \\
\text { speed. } \\
\text { percent } \\
\text { corrected }\end{array}$} & \multicolumn{3}{|c|}{$\begin{array}{c}\text { High-pressure compresscr } \\
\text { inlet conditions }\end{array}$} \\
\hline & & & $\begin{array}{c}\text { Extent, } \\
\text { deg }\end{array}$ & $\triangle \mathrm{TC} / \mathrm{T}^{\mathrm{d}}$ & $\Delta T R / T^{b}$ & & $\begin{array}{c}\text { Extent, } \\
\text { deg }\end{array}$ & $\Delta T C / T^{2}$ & $\Delta T R / T^{b}$ \\
\hline 1 & 4 & 78.9 & 133 & 0.045 & 0.006 & 93.4 & 118 & 0.038 & 0.011 \\
\hline 2 & 4 & 88.9 & --- & $\ldots--$ & --- & 96.0 & --- & ---- & $-\ldots$ \\
\hline 3 & 4 & 99.0 & -- & ---- & $-\ldots$ & 98.6 & -- & ---- & $-\ldots-$. \\
\hline 4 & 2 & 82.7 & 131 & .052 & .005 & 94.8 & $\ldots$ & $\ldots$ & $-\ldots$ \\
\hline 5 & 2 & 92.8 & 133 & .042 & .004 & 97.3 & -- & $-\ldots$ & ---- \\
\hline 6 & 223 & 81.0 & 173 & .042 & .015 & 93.8 & 187 & .033 & .025 \\
\hline 7 & 283 & 91.3 & 178 & .039 & .016 & 96.8 & 196 & .033 & .027 \\
\hline 8 & $2 \& 3$ & 101.9 & $\ldots$ & $-\ldots$ & $\ldots$ & 99.6 & -.. & --- & -- - - \\
\hline 9 & $4 \& 1$ & 78.0 & 181 & .047 & .009 & 92.8 & 192 & .043 & .010 \\
\hline 10 & 481 & 88.0 & -- & $\ldots$ & $\ldots$ & 95.4 & -- & $-\ldots$ &.--- \\
\hline 11 & $\therefore i$ & 137.7 & $\ldots$ & $\ldots$ & $\ldots$ & 97.7 & -- & - . - & $\ldots \ldots$ \\
\hline
\end{tabular}

a $\triangle T C / T$, interisily of circumferential temperature distortion

OATR/T, intensity of radial temperature distortion.

TABLE 2. - RAOIAL INLET TEMPERATURE DISTORIION PATTERNS

\begin{tabular}{|c|c|c|c|c|c|c|c|c|c|c|c|}
\hline \multirow[t]{2}{*}{ Pattern } & \multirow[t]{2}{*}{ Type } & \multirow{2}{*}{$\begin{array}{l}\text { Fan speed } \\
\text { peicent } \\
\text { corrected }\end{array}$} & \multicolumn{4}{|c|}{ Fan inlet conditions } & \multirow{2}{*}{$\begin{array}{l}\text { High-pressure } \\
\text { compressor } \\
\text { speed, } \\
\text { percent } \\
\text { corrected }\end{array}$} & \multicolumn{4}{|c|}{$\begin{array}{c}\text { High-pressure compressor inlet } \\
\text { conditions }\end{array}$} \\
\hline & & & $\begin{array}{l}\text { Extent: } \\
\text { deg }\end{array}$ & $M P R^{d}$ & STCI & $\Delta T R / T C$ & & $\begin{array}{c}\text { Extent } \\
\text { deg }\end{array}$ & MPR ${ }^{a}$ & $\triangle T C / T^{\circ}$ & $S T R / T C$ \\
\hline 1 & Tip & 80.8 & 141 & 1.514 & 0.008 & 0.030 & 91.7 & 128 & 1.599 & 0.008 & 0.006 \\
\hline 2 & Tip & 91.2 & 139 & 1.353 & .009 & .034 & 93.9 & 107 & 1.844 & .010 & .013 \\
\hline 3 & Tip & 95.2 & 134 & 1.791 & .007 & .035 & 95.0 & 106 & 1.431 & .016 & .015 \\
\hline 4 & Hub & 78.4 & 100 & 1.563 & .008 & .072 & 93.3 & 108 & 1.085 & .007 & .069 \\
\hline 5 & Hub & 88.3 & $-\cdots$ & -... & .... & .072 & 96.9 & --- & $-\cdots$ & $\ldots$ & .064 \\
\hline 6 & Hub & 98.4 & ... & $\ldots$ & $\ldots$ & .065 & 99.8 & -- & $-\ldots$ & $\ldots$ & .054 \\
\hline
\end{tabular}

aMultiple-per-revolution factor of circumferential temperature distortion. O $\triangle T C / T$ intenstry of circumferential temparature distortion.

$c_{\triangle T R / T}$ intensity of radial temperature distortion. 
ORIGINAL PAGE IS

OF POOR QUALITY

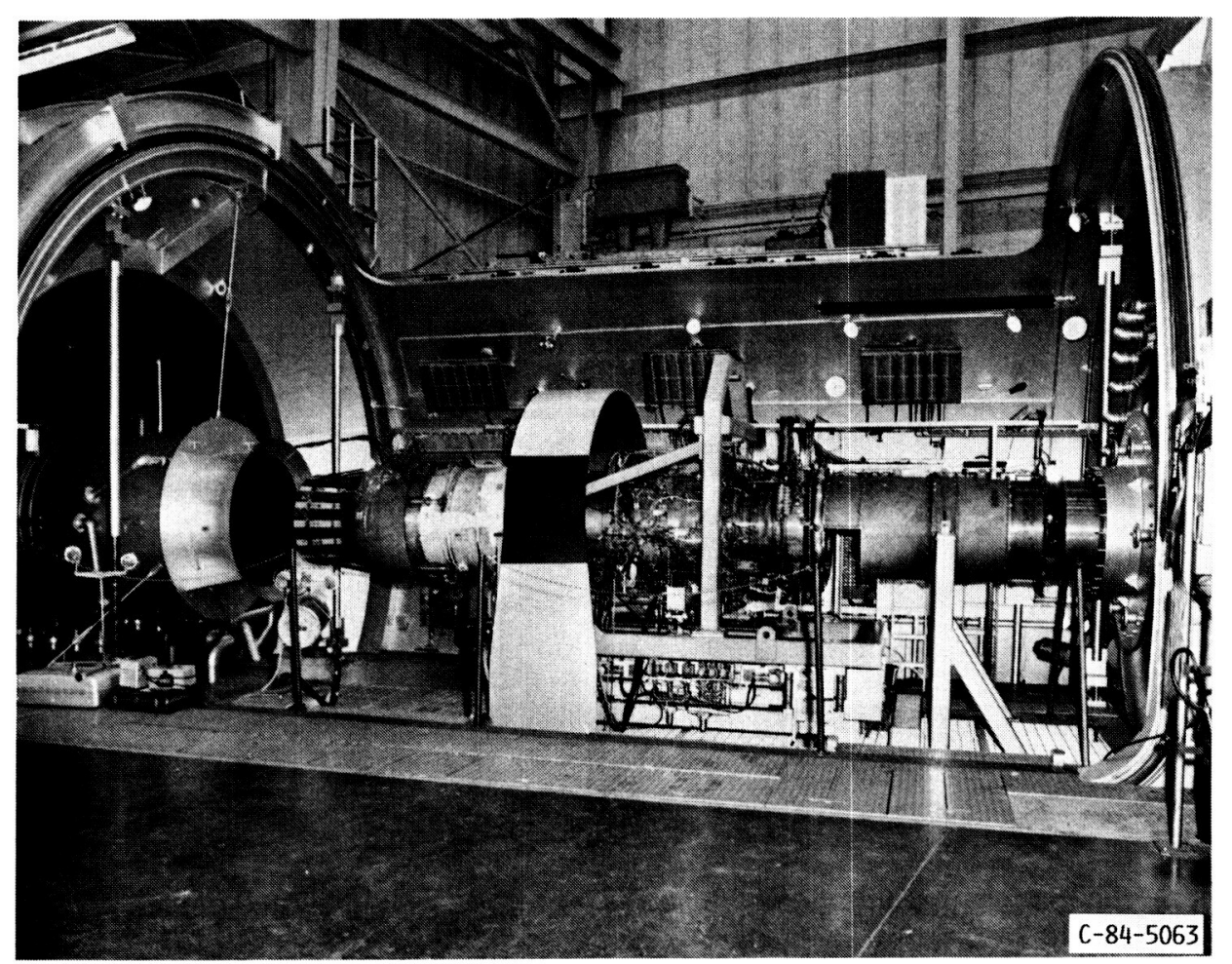

FIGURE 1. - PW1128 ENGINE INSTALLED IN ALTITUDE CHAMBER. 


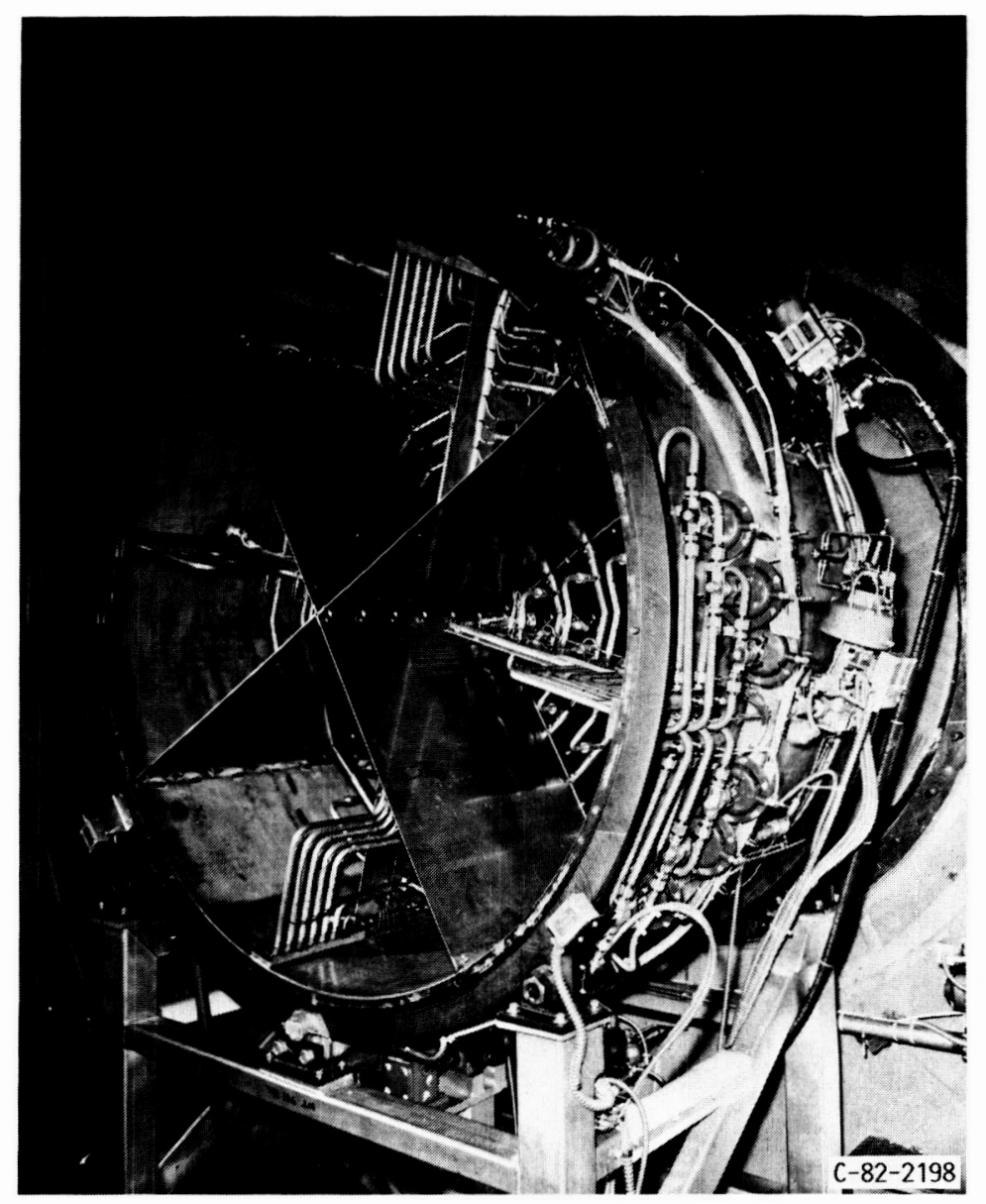

(a) BURNER INSTALLED IN INLET PLENUM.

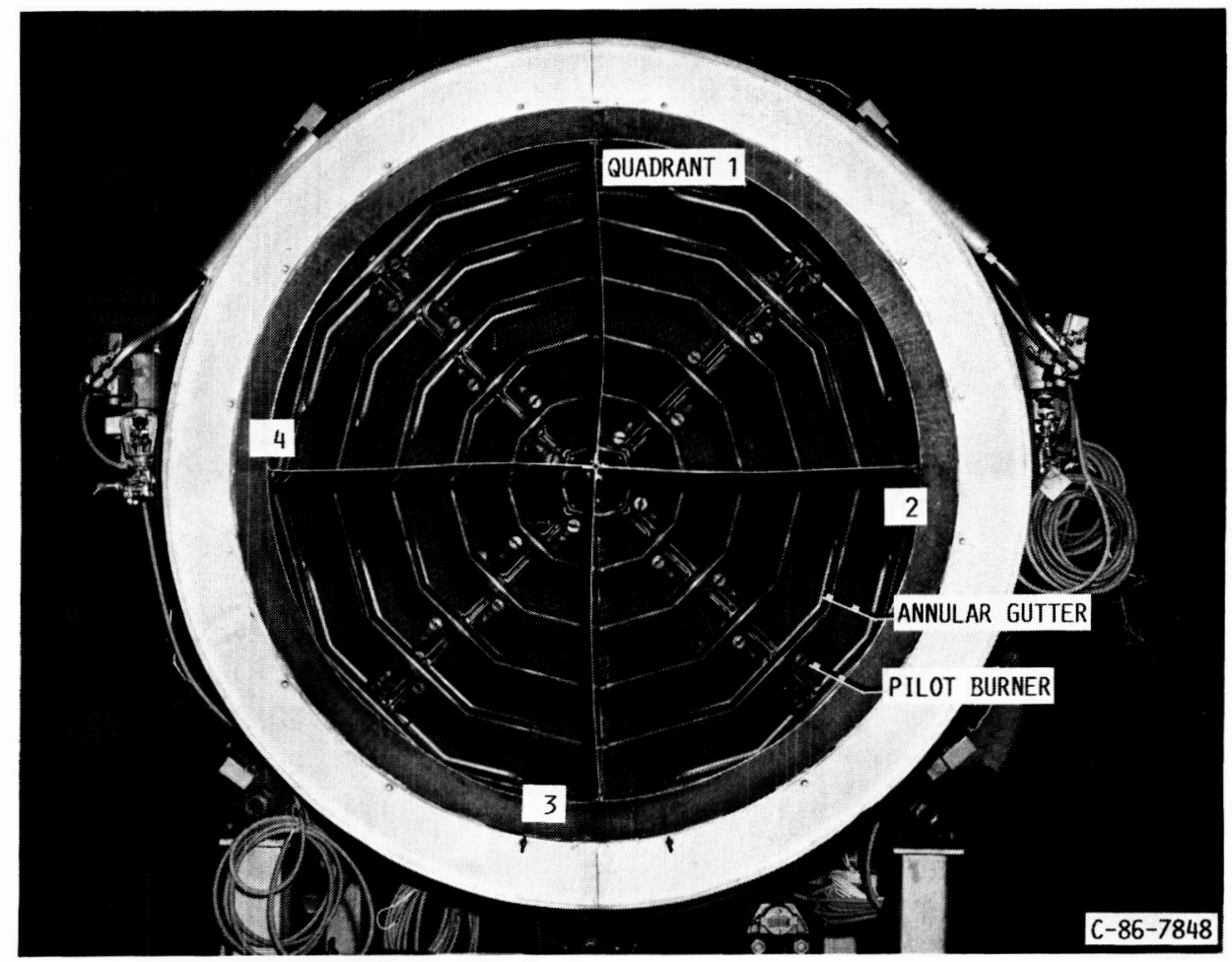

(b) BURNER VIEWED LOOKING UPSTREAM.

FIGURE 2. - HYDROGEN BURNER INSTALLATION. 


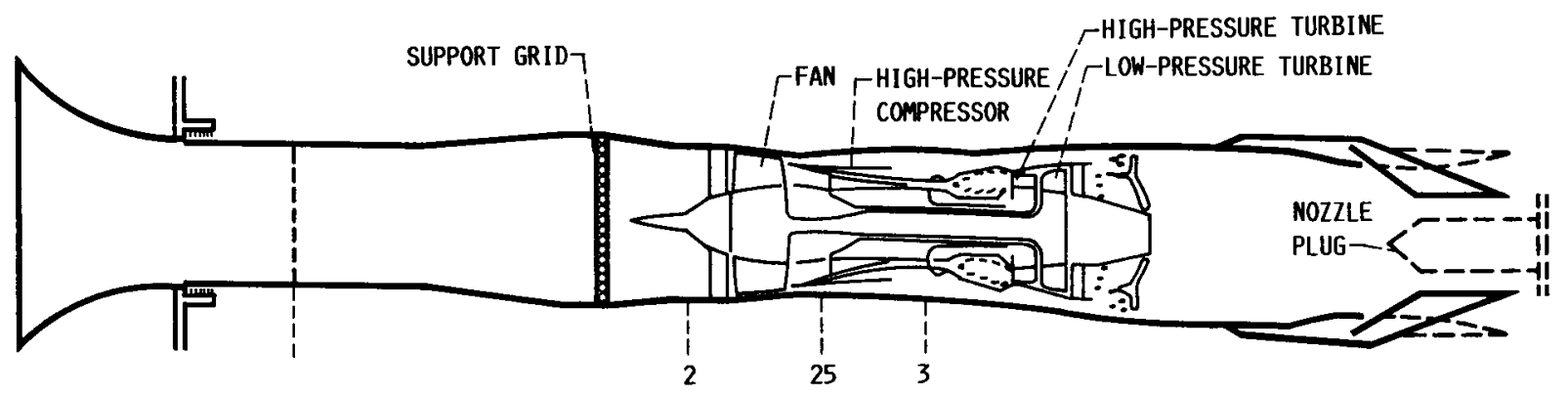

(a) ENGINE AND INSTALLATION.

O STEADY-STATE TOTAL-PRESSURE PROBES.

口 STEADY-STATE STATIC-PRESSURE PROBES

$\triangle$ STEADY-STATE TOTAL-TEMPERATURE PROBES

SOLID SYMBOLS DENOTE HIGH RESPONSE

HALF-SOLID SYMBOLS DENOTE CLOSE COUPLED

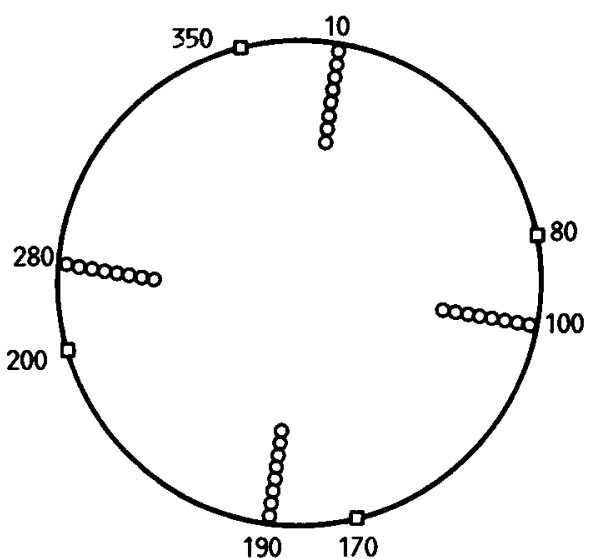

AIRFLOW MEASURING, STATION 1

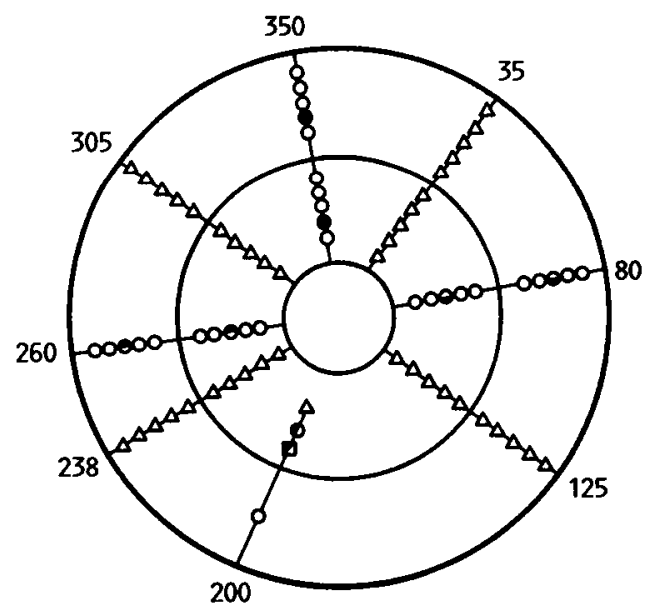

FAN DUCT-COMPRESSOR INLET, STATION 25

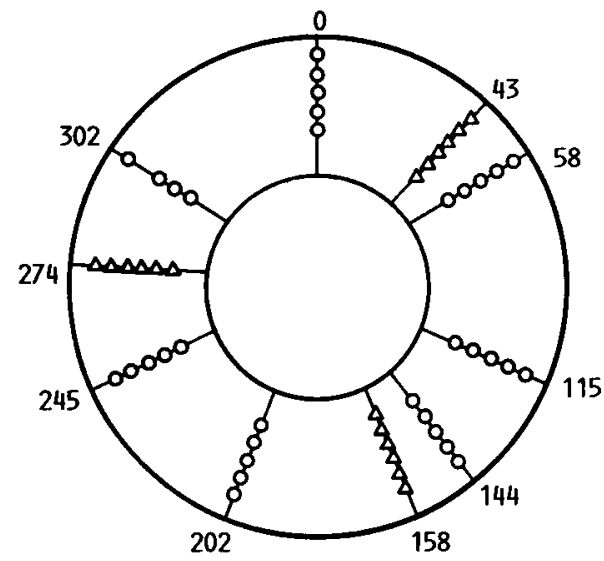

FAN INLET, STATION 2

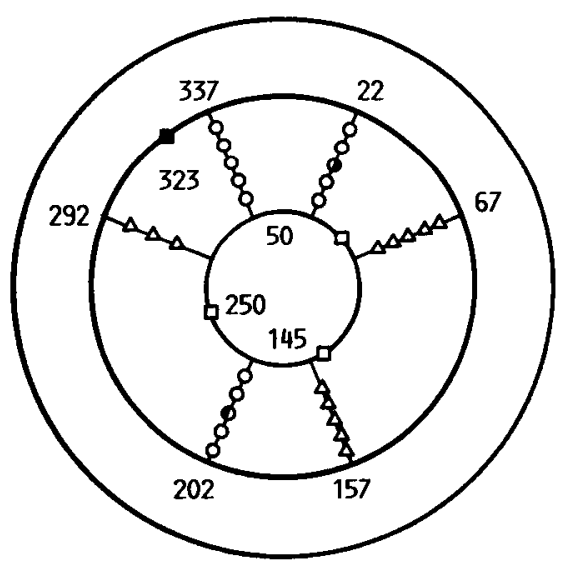

COMPRESSOR EXIT, STATION 3

(b) INSTRUMENTATION LOCATIONS GIVEN IN DEGREES.

FIGURE 3. - SCHEMATIC OF ENGINE AND INSTRUMENTATION STATIONS. 


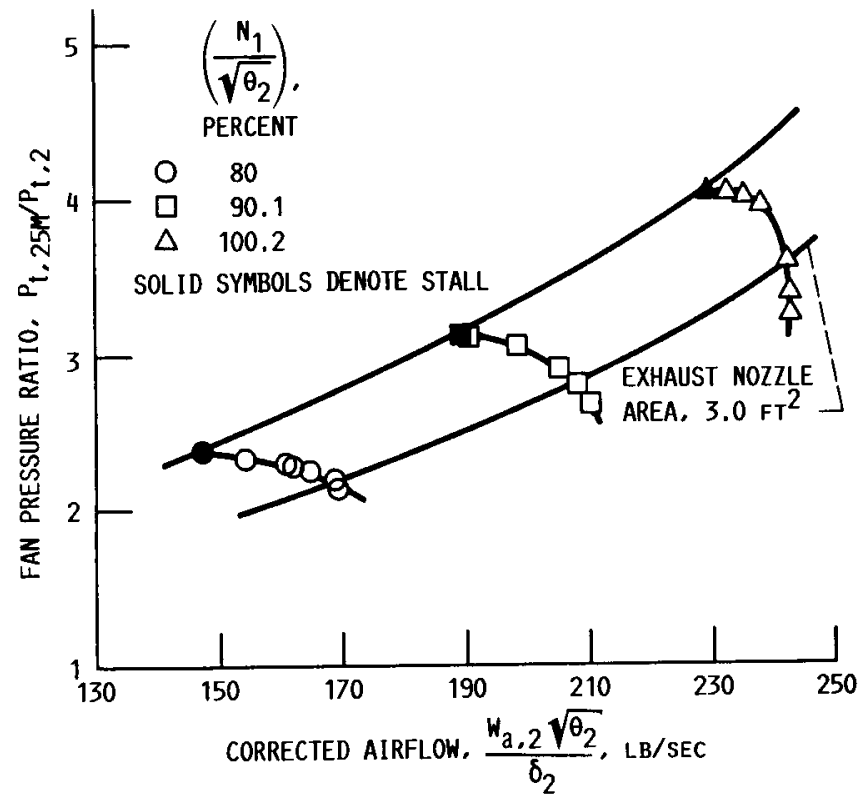

FIGURE 4. - FAN MAP WITH UNIFORM INLET FLOW.

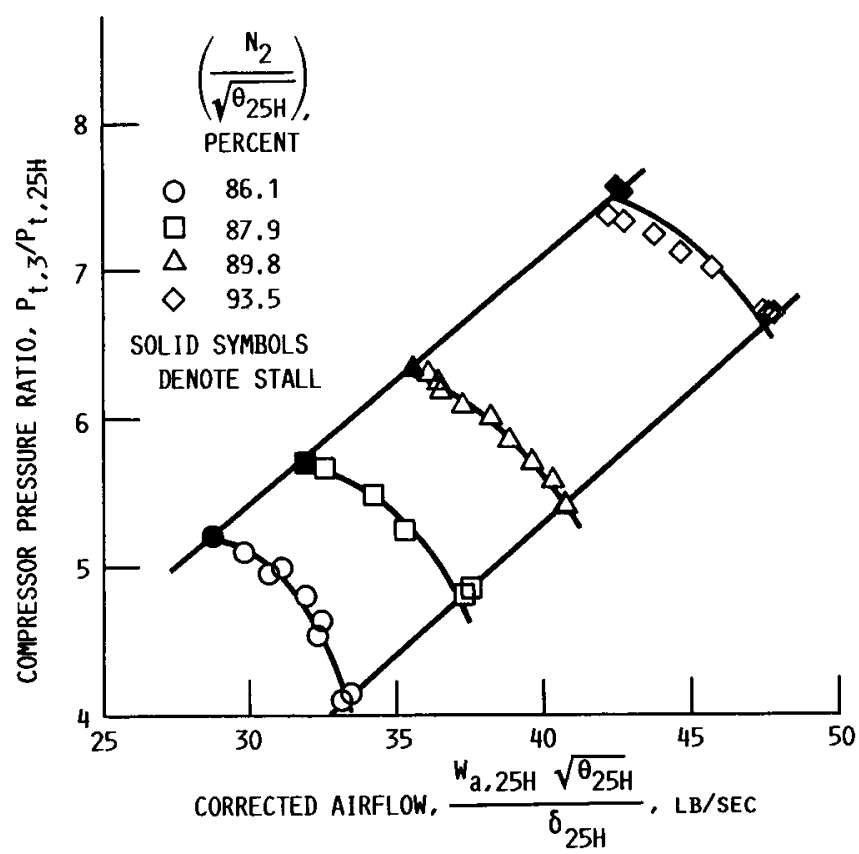

FIGURE 5. - HIGH-PRESSURE COMPRESSOR MAP WITH UNIFORM INLET FLOW.
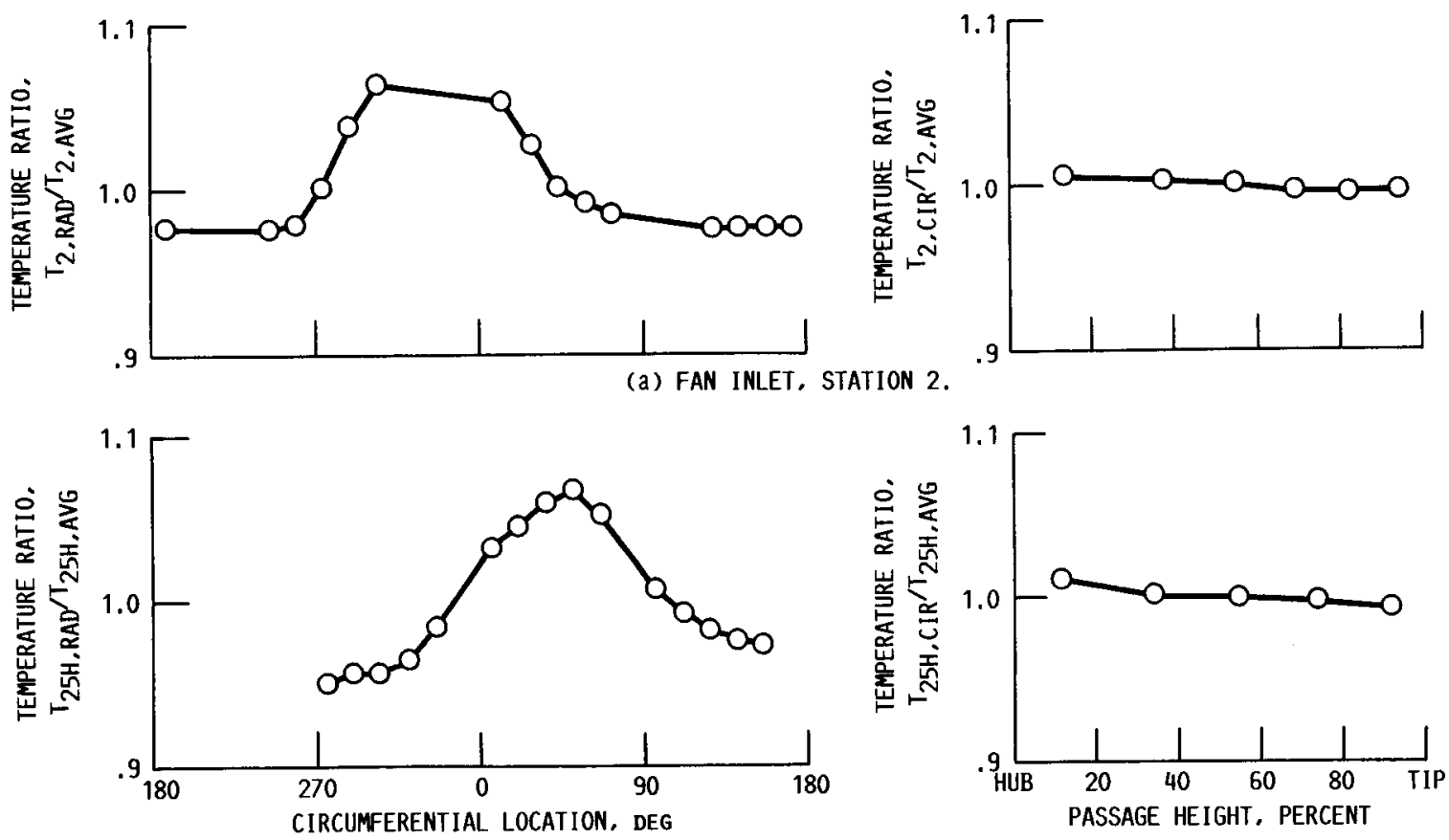

(b) HIGH-PRESSURE COMPRESSOR INLET, STATION $25 \mathrm{H}$.

FIGURE 6. - TYPICAL CIRCUMFERENTIAL TEMPERATURE DISTORTION PROFILES WITH SINGLE QUADRANT HEATING. 

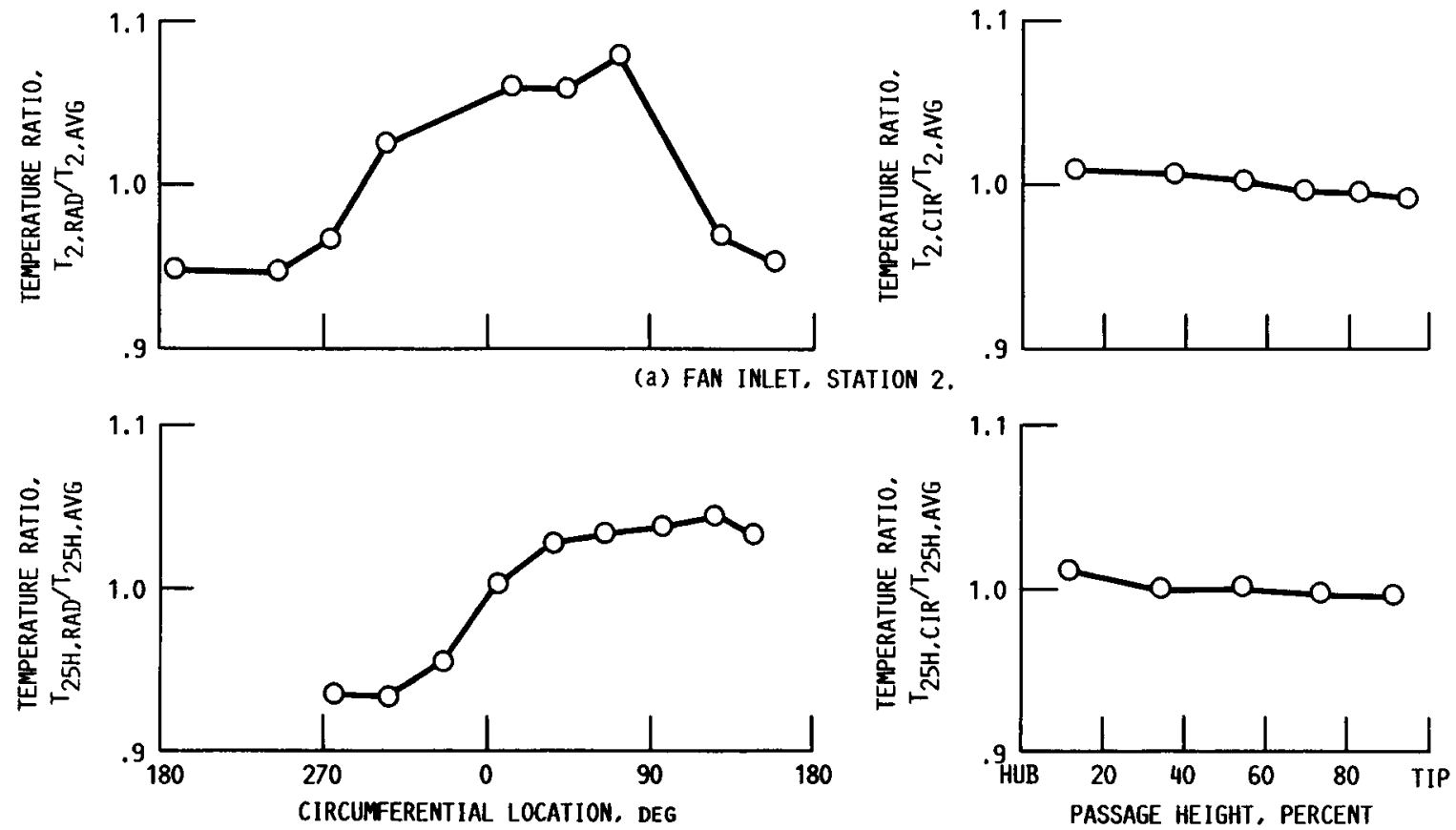

(b) HIGH-PRESSURE COMPRESSOR INLET, STATION 25H.

FIGURE 7. - TYPICAL CIRCUMFERENTIAL TEMPERATURE DISTORTION PROFILES PRODUCED BY HEATING IN TWO ADJACENT QUADRANTS.
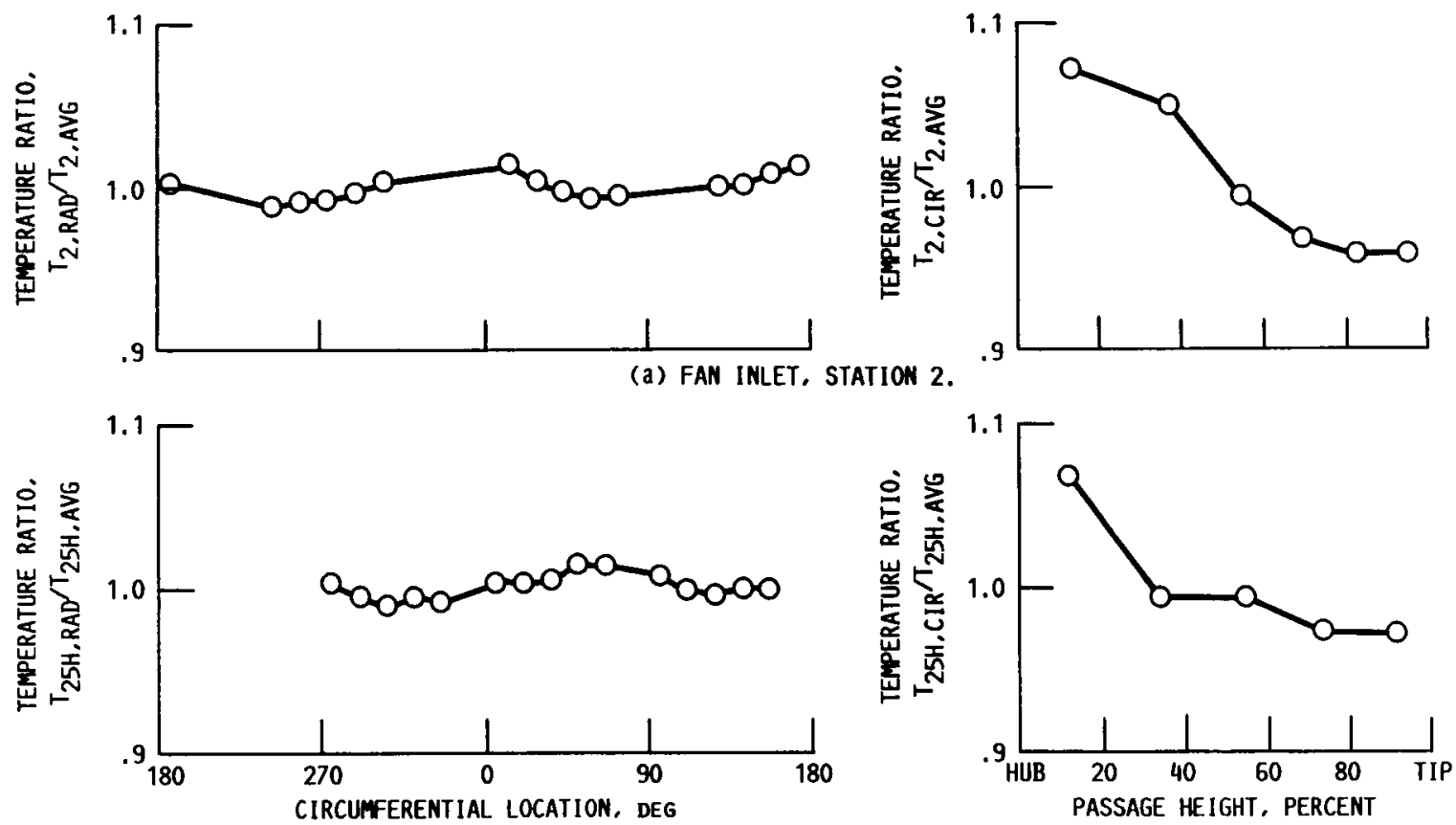

(b) HIGH-PRESSURE COMPRESSOR INLET, STATION $25 \mathrm{H}$.

FIGURE 8. - TYPICAL HUB-RADIAL TEMPERATURE DISTORTION PROFILES. 

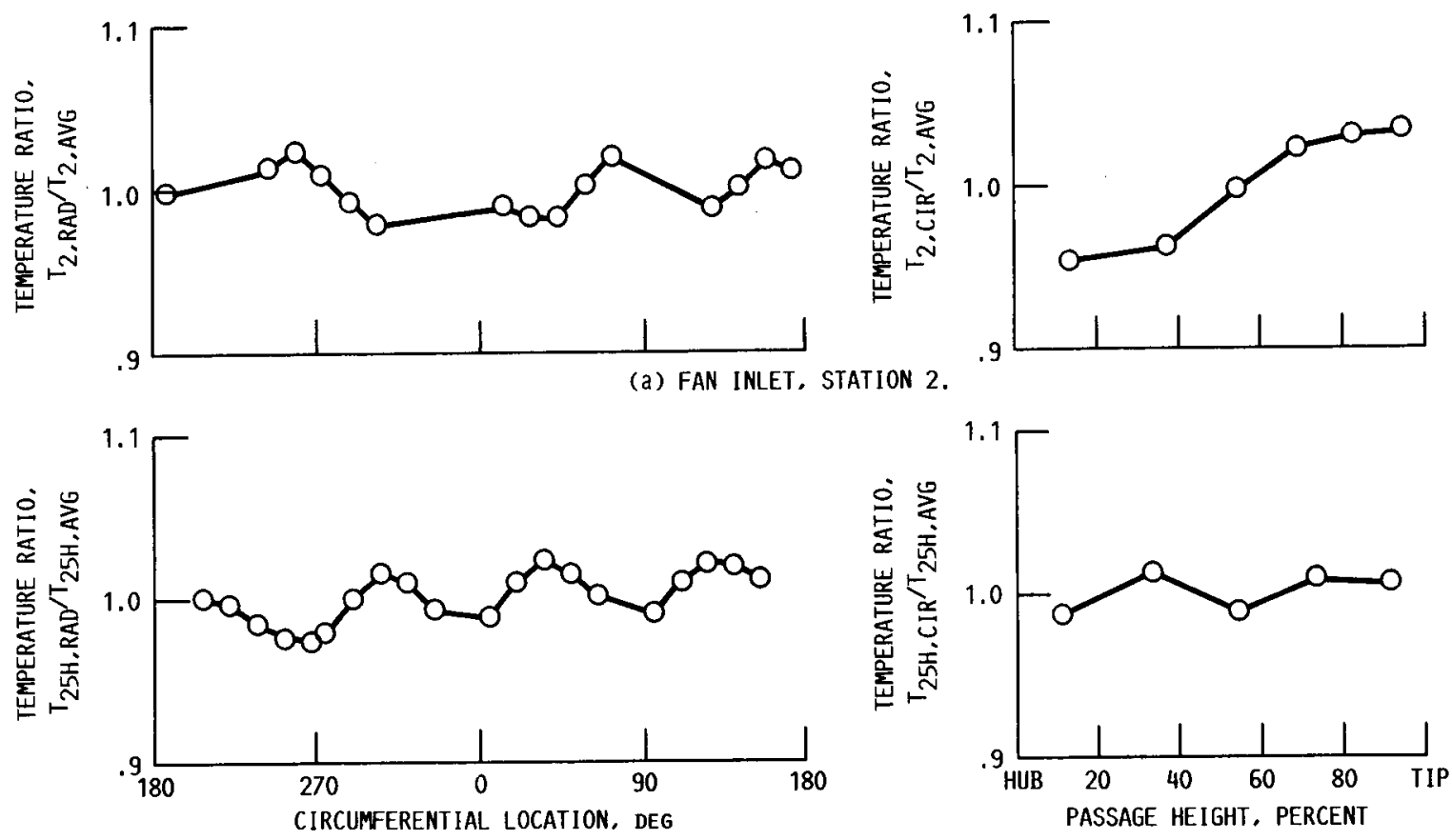

(b) HIGH-PRESSURE COMPRESSOR INLET, STATION 25H.

FIGURE 9. - TYPICAL TIP-RADIAL TEMPERATURE DISTORTION PROFILES.

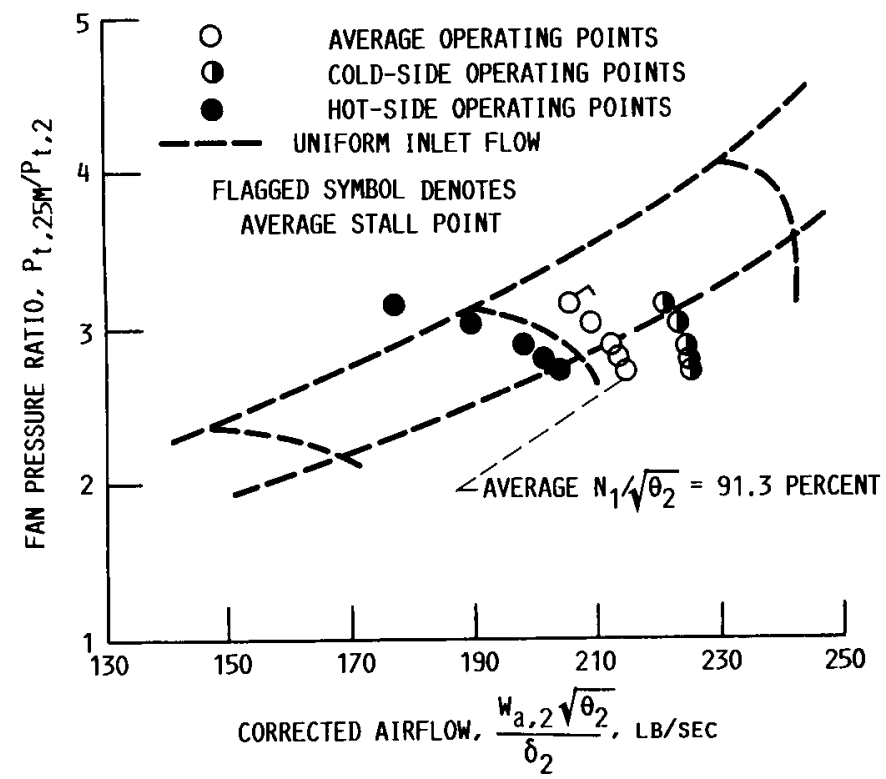

FIgURE 10. - FAN OPERATING POINTS WITH $180^{\circ}$-EXTENT CIRCUMFERENTIAL TEMPERATURE DISTORTION BASED ON PARALLEL COMPRESSOR THEORY.

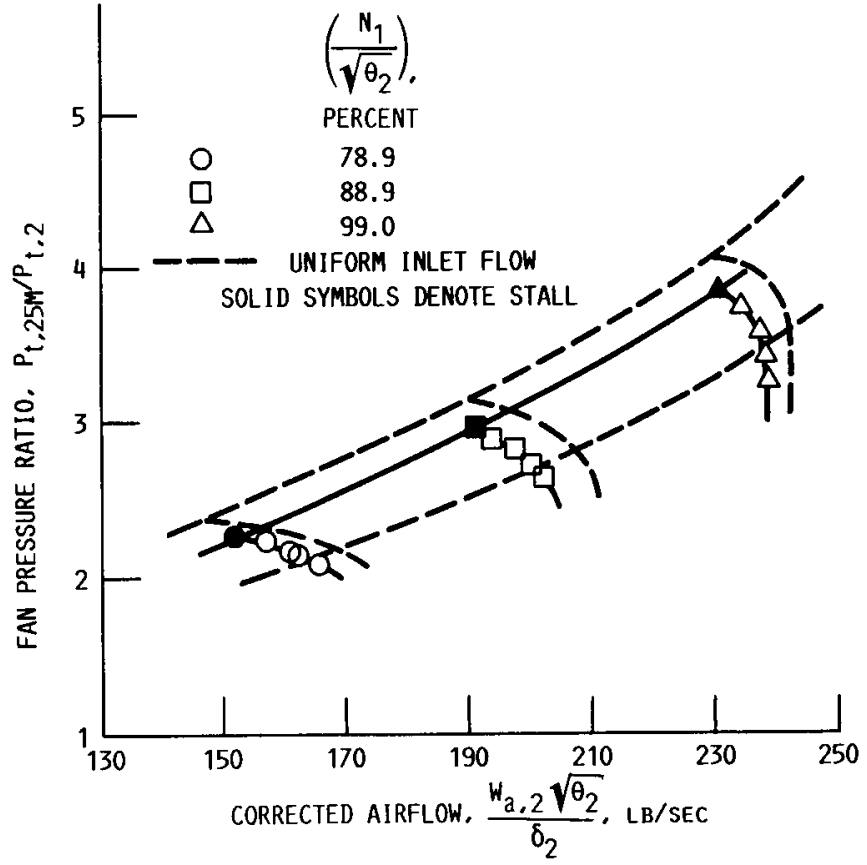

FIGURE 11. - EFFECT OF CIRCUMFERENTIAL FAN INLET TEMPERATURE DISTORTION ON FAN PERFORMANCE: SINGLE QUADRANT (4) HEATING (TOP), PATTERNS $1,2,3$. 


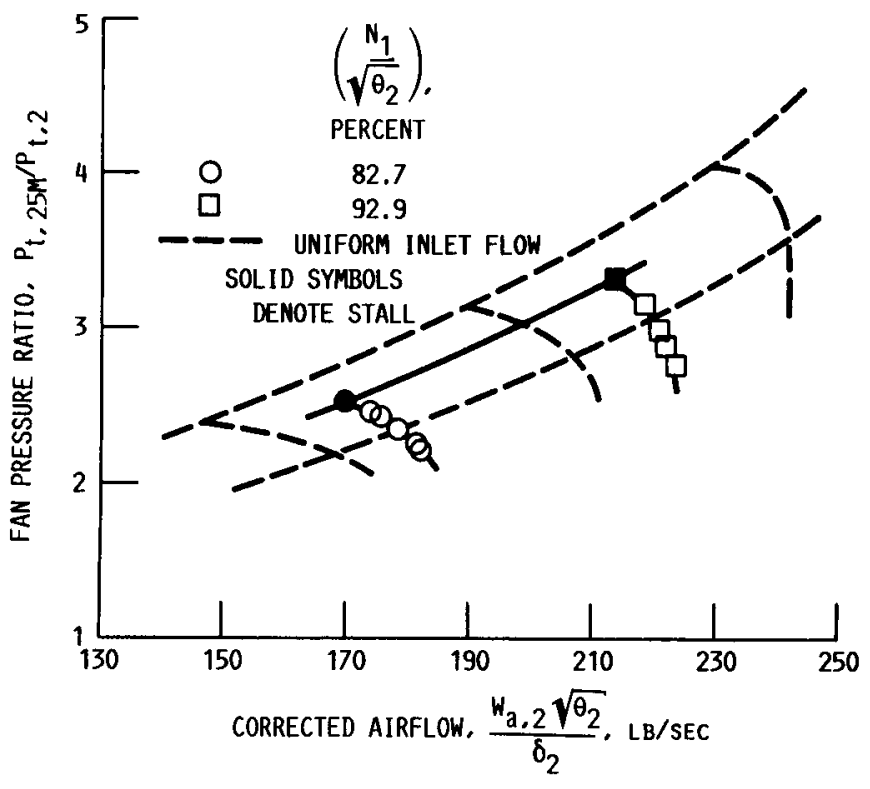

FIGURE 12. - EFFECT OF CIRCUMFERENTIAL FAN INLET TEMPERATURE DISTORTION ON FAN PERFORMANCE : SINGLE QUADRANT (2) HEATING (BOTTOM), PATTERNS 4 AND 5.

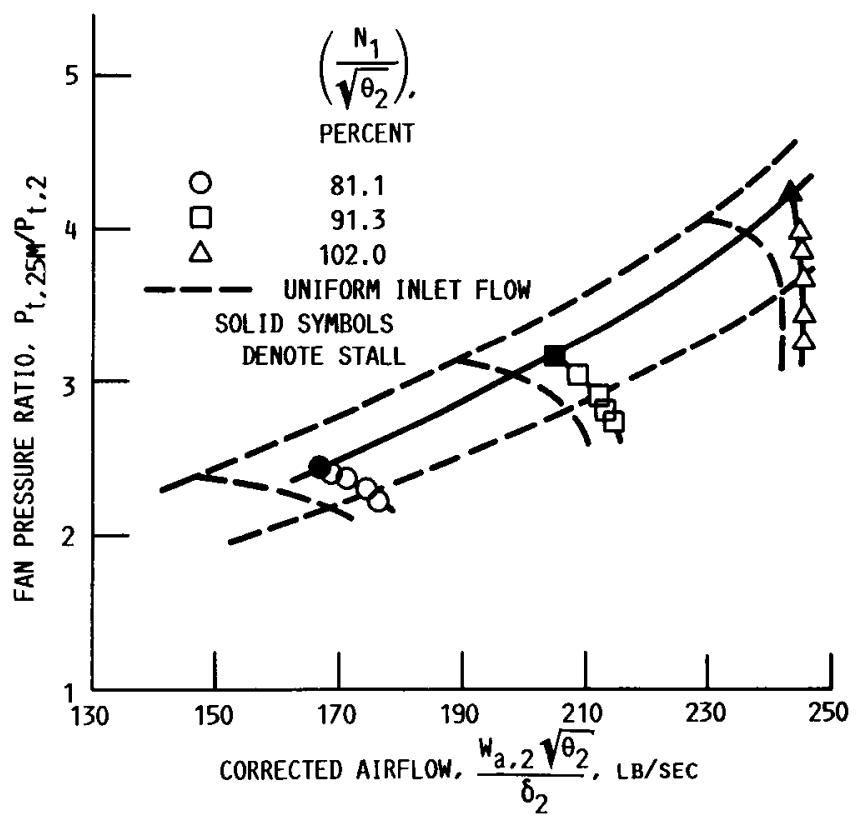

FIGURE 14. - EFFECT OF CIRCUMFERENTIAL FAN INLET TEMPERATURE DISTORTION ON FAN PERFORMANCE: $180^{\circ}$ EXTENT (BOTTOM), PATTERNS 6, 7, AND 8.

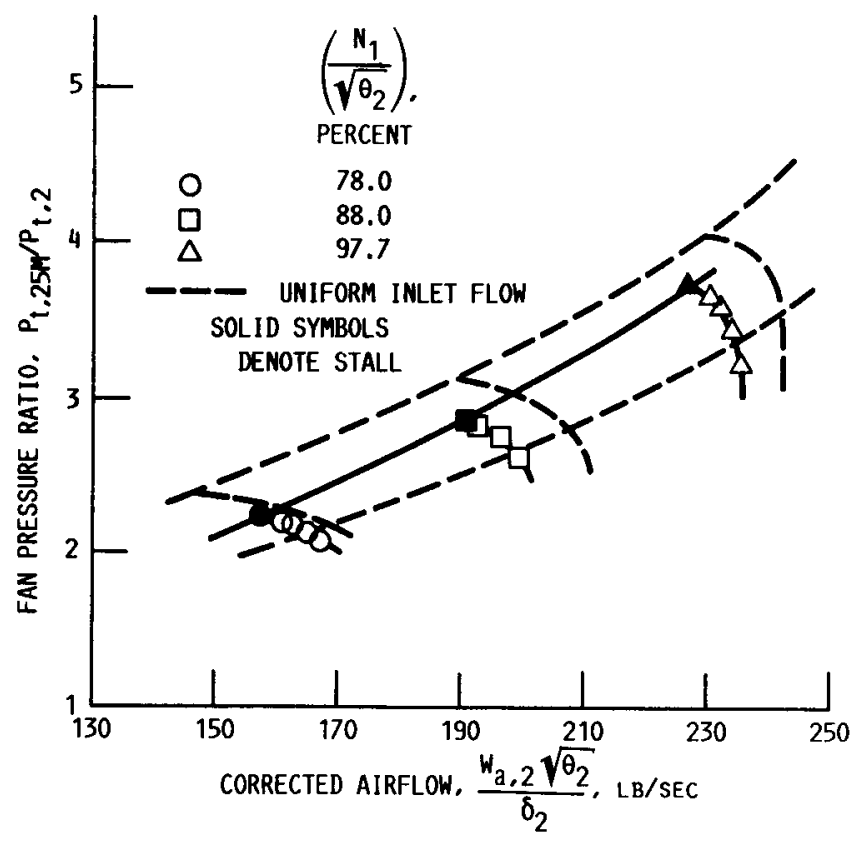

FIGURE 13. - EFFECT OF CIRCUMFERENTIAL FAN INLET TEMPERATURE DISTORTION ON FAN PERFORMANCE; $180^{\circ}$ EXTENT (TOP), PATTERNS 9, 10, AND 11.

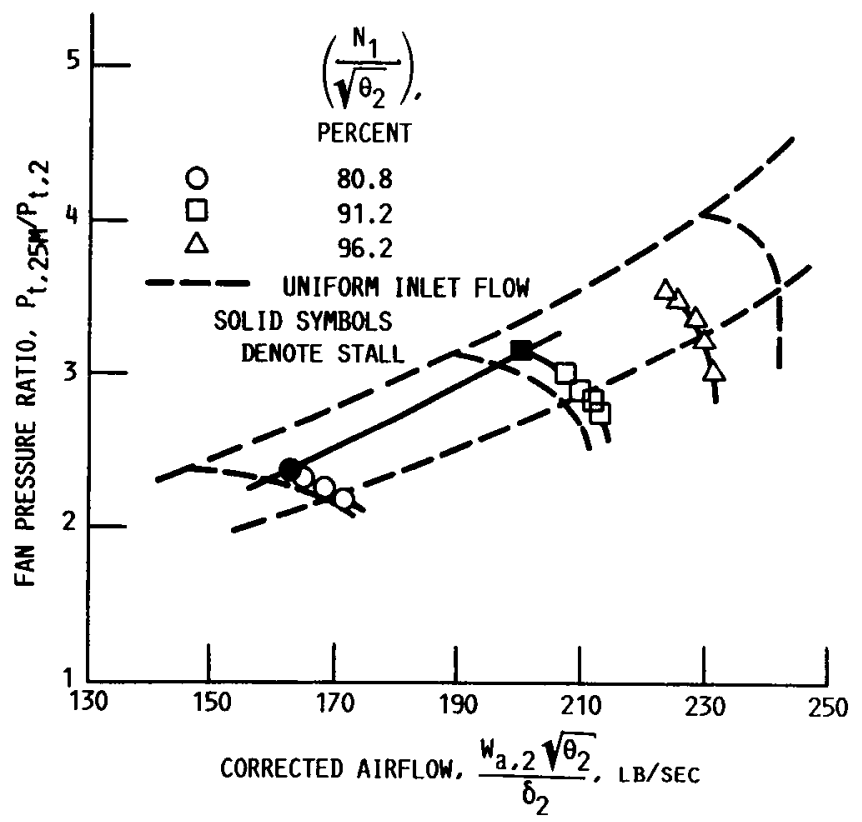

FIGURE 15. - EFFECT OF TIP-RADIAL INLET TEMPERATURE DISTORTION ON FAN STABILITY. 


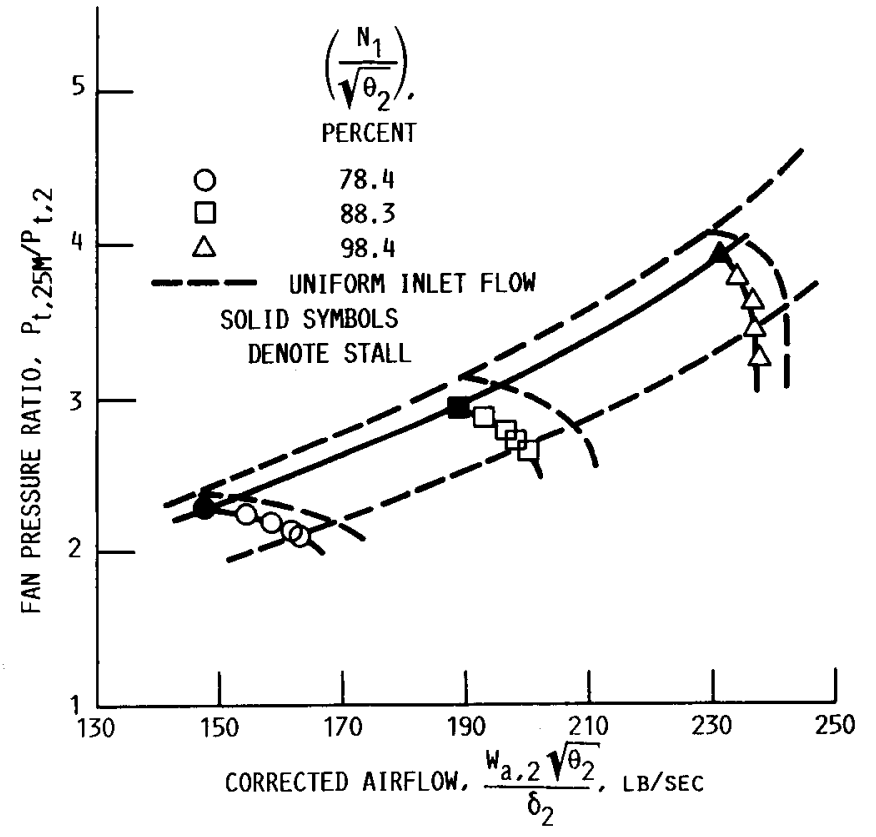

FIGURE 16. - EFFECT OF $360^{\circ}$-EXTENT HUB-RADIAL IMLET TEMPERATURE DISTORTION ON FAN STABILITY.

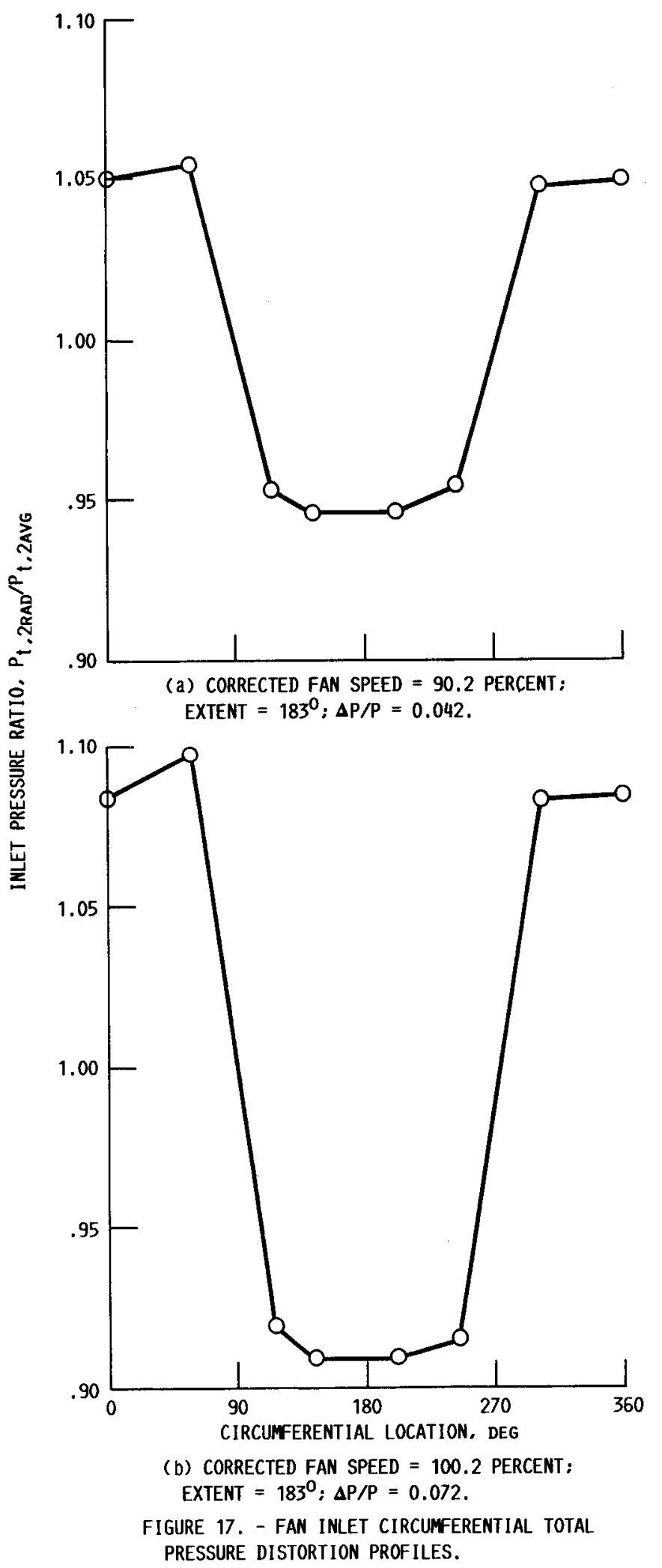




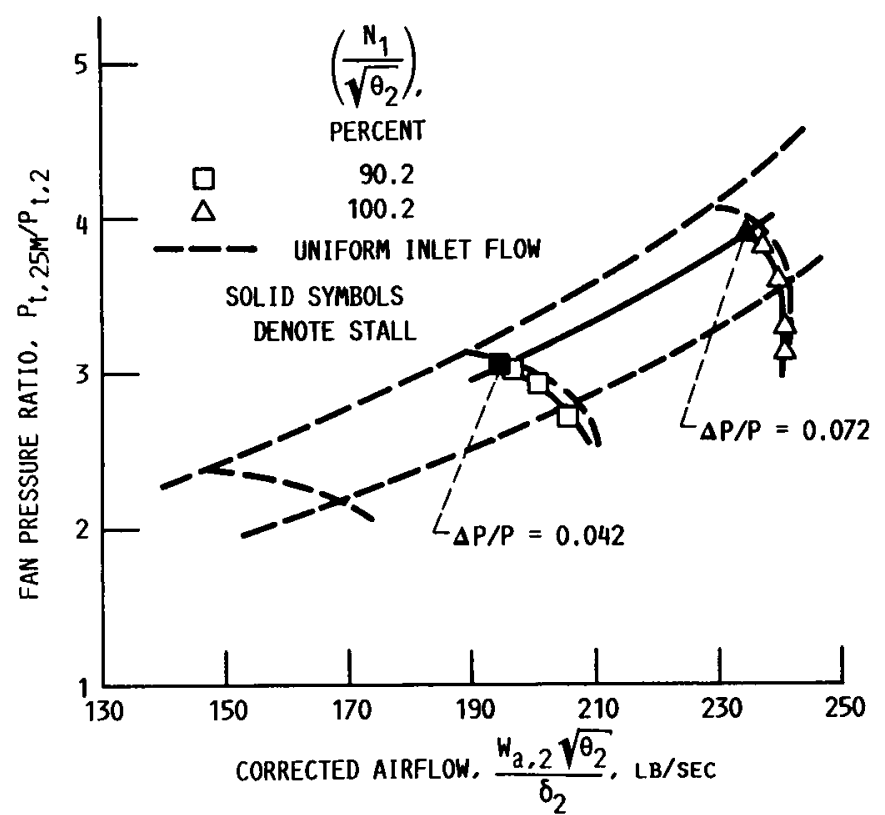

FIGURE 18. - EFFECT OF CIRCUMFERENTIAL INLET TOTAL PRESSURE DISTORTION ON FAN STABILITY.

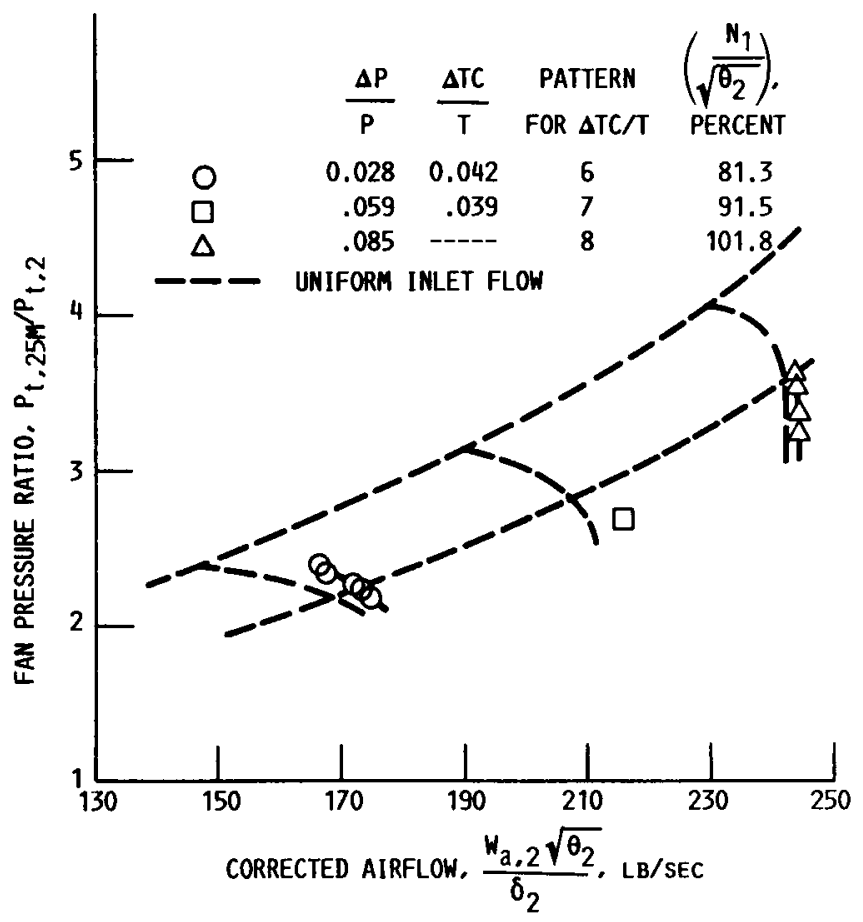

FIGURE 19. - FAN MAP WITH COMBINED PRESSURE AND TEMPERATURE DISTORTION: DISTORTIONS TOGETHER. (PATTERN NUMBERS CORRESPOND TO TABLE 1.)

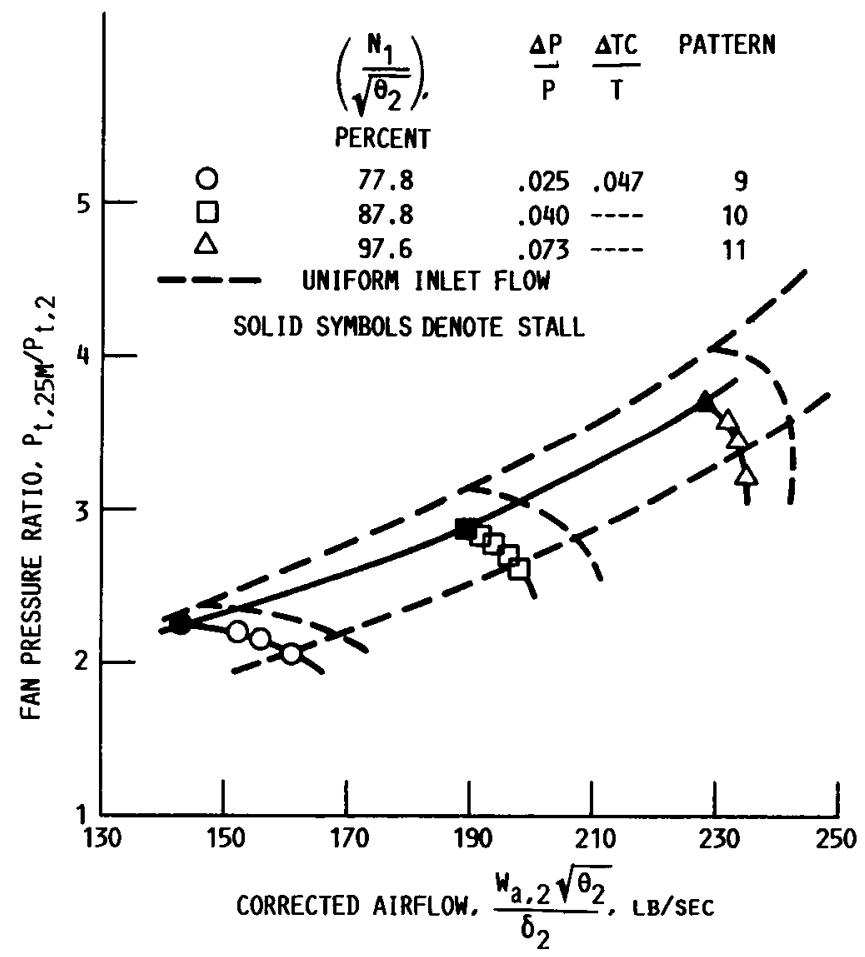

FIGURE 20. - EFFECT OF COMBINED DISTORTION ON FAN PERFORMANCE: DISTORTIONS OPPOSED. (PATTERN NUMBERS CORRESPOND TO TABLE 1.) 


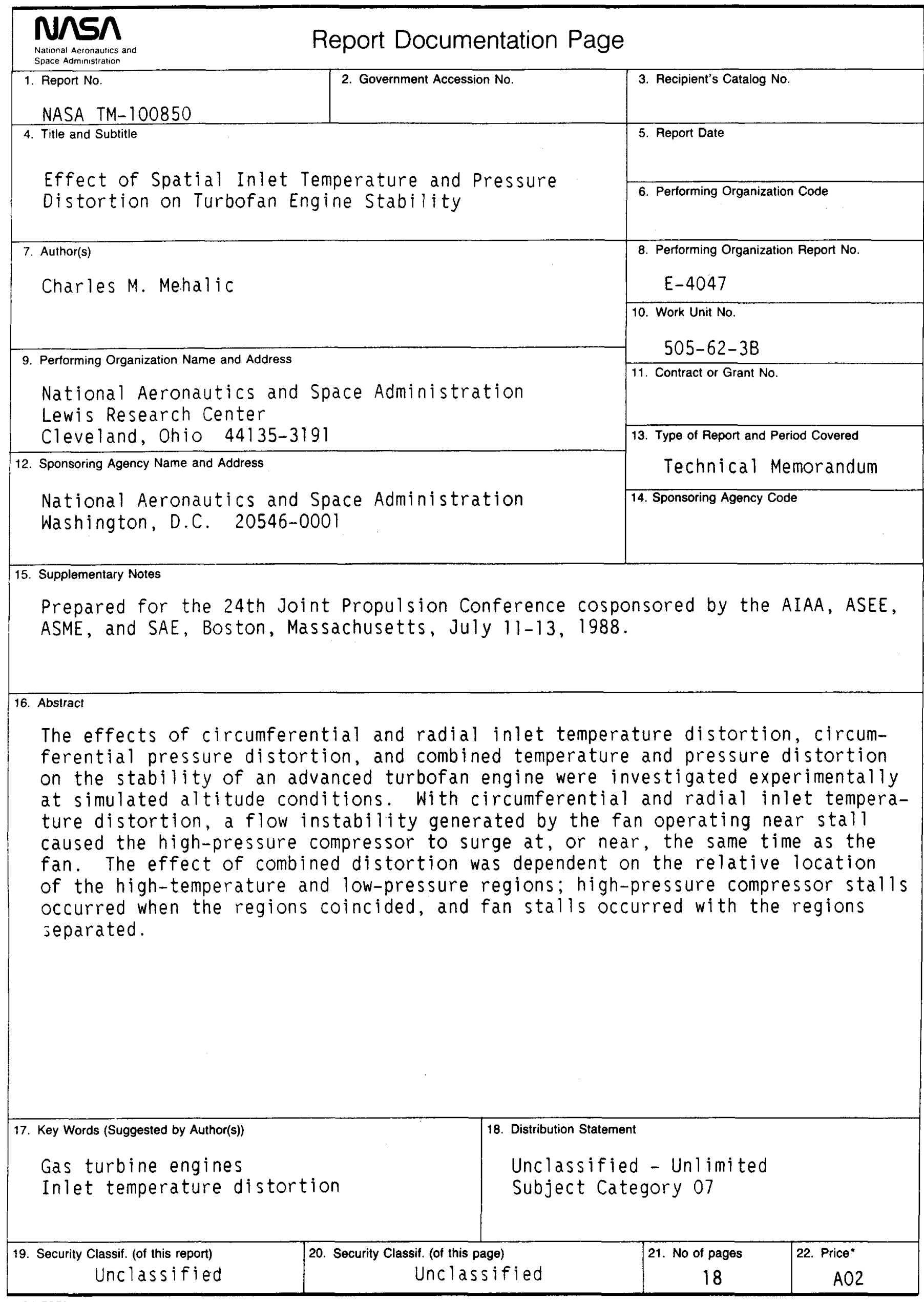

